\title{
The Cabauw Intercomparison campaign for Nitrogen Dioxide measuring Instruments (CINDI): design, execution, and early results
}

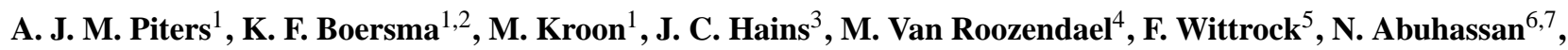 \\ C. Adams $^{8}$, M. Akrami ${ }^{8}$, M. A. F. Allaart ${ }^{1}$, A. Apituley ${ }^{10,1}$, S. Beirle ${ }^{24}$, J. B. Bergwerff ${ }^{10}$, A. J. C. Berkhout ${ }^{10}$, \\ D. Brunner ${ }^{11}$, A. Cede ${ }^{12,7}$, J. Chong ${ }^{13}$, K. Clémer ${ }^{4}$, C. Fayt ${ }^{4}$, U. Frieß ${ }^{14}$, L. F. L. Gast ${ }^{10}$, M. Gil-Ojeda ${ }^{9}$, F. Goutail ${ }^{15}$, \\ R. Graves ${ }^{16}$, A. Griesfeller ${ }^{15}$, K. Großmann ${ }^{14}$, G. Hemerijckx ${ }^{4}$, F. Hendrick ${ }^{4}$, B. Henzing ${ }^{17}$, J. Herman ${ }^{12,7}$, \\ C. Hermans ${ }^{4}$, M. Hoexum ${ }^{10}$, G. R. van der Hoff ${ }^{10}$, H. Irie ${ }^{18}$, P. V. Johnston ${ }^{19}$, Y. Kanaya ${ }^{18}$, Y. J. Kim ${ }^{13}$, \\ H. Klein Baltink ${ }^{1}$, K. Kreher ${ }^{19}$, G. de Leeuw ${ }^{17,20,27}$, R. Leigh ${ }^{16}$, A. Merlaud ${ }^{4}$, M. M. Moerman ${ }^{17}$, P. S. Monks ${ }^{16}$, \\ G. H. Mount ${ }^{21}$, M. Navarro-Comas ${ }^{9}$, H. Oetjen $^{22}$, A. Pazmino ${ }^{15}$, M. Perez-Camacho ${ }^{9}$, E. Peters ${ }^{5}$, A. du Piesanie ${ }^{1}$, \\ G. Pinardi ${ }^{4}$, O. Puentedura ${ }^{9}$, A. Richter ${ }^{5}$, H. K. Roscoe ${ }^{23}$, A. Schönhardt ${ }^{5}$, B. Schwarzenbach ${ }^{11}$, R. Shaiganfar Sch $^{24}$, \\ W. Sluis ${ }^{1}$, E. Spinei ${ }^{21}$, A. P. Stolk ${ }^{10}$, K. Strong ${ }^{8}$, D. P. J. Swart ${ }^{10}$, H. Takashima ${ }^{18}$, T. Vlemmix ${ }^{1}$, M. Vrekoussis ${ }^{5,26}$,

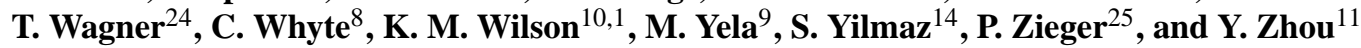 \\ ${ }^{1}$ Royal Netherlands Meteorological Institute (KNMI), De Bilt, The Netherlands \\ ${ }^{2}$ Technical University Eindhoven (TUE), Eindhoven, The Netherlands \\ ${ }^{3}$ Maryland Department of the Environment (MDE), Baltimore, MD, USA \\ ${ }^{4}$ Belgian Institute for Space Aeronomy (BIRA-IASB), Brussels, Belgium \\ ${ }^{5}$ Institute of Environmental Physics (IUP), University of Bremen, Bremen, Germany \\ ${ }^{6}$ Morgan State University (MSU), Baltimore, MD, USA \\ ${ }^{7}$ NASA/Goddard Space Flight Center (GSFC), Greenbelt, MD, USA \\ ${ }^{8}$ Department of Physics, University of Toronto, Toronto, Ontario, Canada \\ ${ }^{9}$ National Institute for Aerospace technology (INTA), Madrid, Spain \\ ${ }^{10}$ National Institute for Public Health and the Environment (RIVM), Bilthoven, The Netherlands \\ ${ }^{11}$ Swiss Federal Laboratories for Materials Science and Technology (EMPA), Dübendorff, Switzerland \\ ${ }^{12}$ University of Maryland, Baltimore County (UMBC), Catonsville, MD, USA \\ ${ }^{13}$ Gwangju Institute of Science and Technology, Gwangiu, Republic of Korea \\ ${ }^{14}$ Institute of Environmental Physics, University of Heidelberg, Heidelberg, Germany \\ ${ }^{15}$ Laboratoire Atmosphères, Milieux, Observations Spatiales (LATMOS), Guyancourt, France \\ ${ }^{16}$ Department of Chemistry, University of Leicester, Leicester, UK \\ ${ }^{17}$ Netherlands Organization for Applied Scientific Research (TNO), Utrecht, The Netherlands \\ ${ }^{18}$ Research Institute for Global Change, JAMSTEC, Yokohama, Japan \\ ${ }^{19}$ National Institute of Water \& Atmospheric Research (NIWA), Lauder, New Zealand \\ ${ }^{20}$ Finnish Meteorological Institute (FMI), Helsinki, Finland \\ ${ }^{21}$ Laboratory for Atmospheric Research, Washington State University (WSU), Pullman, WA, USA \\ ${ }^{22}$ School of Chemistry, University of Leeds, Leeds, UK \\ ${ }^{23}$ British Antarctic Survey (BAS), Cambridge, UK \\ ${ }^{24}$ Max Planck Institute for Chemistry (MPIC), Mainz, Germany \\ ${ }^{25}$ Laboratory of Atmospheric Chemistry, Paul Scherrer Institut (PSI), Villigen, Switzerland \\ ${ }^{26}$ Research Center for Atmospheric Physics and Climatology, Academy of Athens, Athens, Greece \\ ${ }^{27}$ Department of Physics, University of Helsinki, Helsinki, Finland
}

Correspondence to: A. J. M. Piters (piters@knmi.nl)

Received: 19 August 2011 - Published in Atmos. Meas. Tech. Discuss.: 16 September 2011 Revised: 10 February 2012 - Accepted: 14 February 2012 - Published: 27 February 2012

Published by Copernicus Publications on behalf of the European Geosciences Union. 
Abstract. From June to July 2009 more than thirty different in-situ and remote sensing instruments from all over the world participated in the Cabauw Intercomparison campaign for Nitrogen Dioxide measuring Instruments (CINDI). The campaign took place at KNMI's Cabauw Experimental Site for Atmospheric Research (CESAR) in the Netherlands. Its main objectives were to determine the accuracy of state-ofthe-art ground-based measurement techniques for the detection of atmospheric nitrogen dioxide (both in-situ and remote sensing), and to investigate their usability in satellite data validation. The expected outcomes are recommendations regarding the operation and calibration of such instruments, retrieval settings, and observation strategies for the use in ground-based networks for air quality monitoring and satellite data validation. Twenty-four optical spectrometers participated in the campaign, of which twenty-one had the capability to scan different elevation angles consecutively, the so-called Multi-axis DOAS systems, thereby collecting vertical profile information, in particular for nitrogen dioxide and aerosol. Various in-situ samplers and lidar instruments simultaneously characterized the variability of atmospheric trace gases and the physical properties of aerosol particles. A large data set of continuous measurements of these atmospheric constituents has been collected under various meteorological conditions and air pollution levels. Together with the permanent measurement capability at the CESAR site characterizing the meteorological state of the atmosphere, the CINDI campaign provided a comprehensive observational data set of atmospheric constituents in a highly polluted region of the world during summertime. First detailed comparisons performed with the CINDI data show that slant column measurements of $\mathrm{NO}_{2}, \mathrm{O}_{4}$ and $\mathrm{HCHO}$ with MAX-DOAS agree within 5 to $15 \%$, vertical profiles of $\mathrm{NO}_{2}$ derived from several independent instruments agree within $25 \%$ of one another, and MAX-DOAS aerosol optical thickness agrees within 20-30\% with AERONET data. For the in-situ $\mathrm{NO}_{2}$ instrument using a molybdenum converter, a bias was found as large as 5 ppbv during day time, when compared to the other in-situ instruments using photolytic converters.

\section{Introduction}

The Cabauw Intercomparison campaign for Nitrogen Dioxide Measuring Instruments (CINDI) was conducted in JuneJuly 2009 with the purpose of intercomparing and intercalibrating ground-based instruments measuring nitrogen dioxide $\left(\mathrm{NO}_{2}\right)$, of which the observations can be used for the validation of tropospheric $\mathrm{NO}_{2}$ retrievals from satellite observations. The campaign was based in Cabauw, the Netherlands, a place with mainly agriculture in the direct proximity but at $<40 \mathrm{~km}$ distance from the 4 largest cities of the Netherlands, the closest of which is Utrecht $(18 \mathrm{~km})$. The Cabauw
Experimental Site for Atmospheric Research (CESAR) is managed by the Royal Netherlands Meteorological Institute (KNMI). CINDI was building on previous and more exploratory campaigns focusing on air pollution measurement techniques and satellite data validation (e.g. DANDELIONS 2005 and 2006 in Brinksma et al., 2008; Hains et al., 2010, and FORMAT in 2002 and 2003, see Heckel et al., 2005; Hak et al., 2005). The CINDI campaign was performed under the auspices of the European Space Agency (ESA), of the International Network for Detection of Atmospheric Composition Change (NDACC), and of the EU Framework 6's Access to Remote Sensing of Atmospheric Constituents from Space - Troposat-2 (ACCENT-AT2) Network of Excellence, and Global Earth Observation and Monitoring of the Atmosphere (GEOMon) Integrated Project. ESA promotes accuracy of ground-based measurements that can be used for satellite data validation; NDACC promotes excellence in measurements of atmospheric composition; and GEOMon has been responsible for maintaining and developing networks of ground-based remote sensors, in support of the preparation of the Global Monitoring for Environment and Security (GMES) Atmospheric Service.

The CINDI campaign was organized around two main objectives. The first one was to determine the accuracy of state-of-the-art ground-based atmospheric $\mathrm{NO}_{2}$ measurement techniques, to test these techniques under different atmospheric conditions, and to improve them, in order to provide a local reference for the validation of global satellite data retrievals. This responds to the need to develop and maintain accurate ground-based measurement capability, including the detection of vertical profiles of $\mathrm{NO}_{2}$, expressed e.g. in the conclusions of the ACCENT-AT2 supported workshop on "Tropospheric $\mathrm{NO}_{2}$ measured by satellites" (Piters, 2007). The second objective was to investigate the potential of the different ground-based instruments for satellite data validation, focusing on the possibility of mapping the threedimensional $\mathrm{NO}_{2}$ distribution. The aim of CINDI is to provide an estimate of the accuracy of retrieved tropospheric $\mathrm{NO}_{2}$ columns and profiles for the participating instruments under different atmospheric conditions (pollution levels, meteorological state) and viewing geometries and to provide a set of recommendations concerning instrumentation, calibration, and measurement and retrieval strategies for the validation of satellite-derived tropospheric $\mathrm{NO}_{2}$ data. A better understanding of the variability of $\mathrm{NO}_{2}$ could very well improve current state-of-the-art air quality models.

These main objectives resulted in a two-phase approach. The first phase of CINDI, running from 8 June to 8 July, consisted of an extensive intercomparison campaign for $\sim 22$ multi-axis and zenith-sky spectrometers that were lined up together at Cabauw. The result of this study, showing that the slant columns of $\mathrm{NO}_{2}$ and $\mathrm{O}_{4}$ measured by these instruments, when retrieved with standardized setting, are mostly consistent within 5 to $10 \%$, has been published in Roscoe et al. (2010). In the second phase of CINDI, running from 
9 July to 26 July, the observation modes and locations of the instruments were optimized for investigating the influence of different viewing geometries and for investigating spatial variability on the scale of a typical satellite ground pixel footprint over the measurement site.

Measuring the vertical distribution of $\mathrm{NO}_{2}$ was of key importance in the CINDI campaign as its uncertainty is a major source of error in the retrieval of tropospheric $\mathrm{NO}_{2}$ columns from both ground-based and satellite based observations. Next to the passive remote sensors like the MultiAXis Differential Optical Absorption Spectrometers (MAXDOAS, Hönninger et al., 2004), an active remote sensing system consisting of a lidar instrument developed at RIVM (Volten et al., 2009) measured the vertical distribution of $\mathrm{NO}_{2}$ in the boundary layer. Additionally four in-situ chemiluminescence analysers were placed at several levels in the Cabauw tower, providing valuable information about the temporal evolution of the $\mathrm{NO}_{2}$ vertical profile in the lowest $200 \mathrm{~m}$, and monitoring the boundary layer development. Simultaneous observations at $3 \mathrm{~m}$ altitude provided the opportunity to demonstrate that there is a bias between the insitu instruments working with the widely-used molybdenum $\mathrm{NO}_{2}$ to $\mathrm{NO}$ converter, which is also sensitive to other nitrate containing chemical compounds such as peroxyacetyl nitrate (PAN; Dunlea et al., 2007), and the systems working with the more recent photolytic converters which do not suffer from this interference effect (Fehsenfeld et al., 1990). In addition six experimental flights of a newly developed balloon-borne sonde measured the $\mathrm{NO}_{2}$ vertical profile from the ground up to $5 \mathrm{~km}$ altitude (Sluis et al., 2010). The CINDI $\mathrm{NO}_{2}$ profile data were intercompared to evaluate the various profiling techniques, pointing out different strengths and weaknesses, and to make suggestions for future retrieval improvement (see Sect. 4.4).

Another element of CINDI was the measurement of a variety of atmospheric constituents. Besides the retrieval of $\mathrm{NO}_{2}$ columns and profiles simultaneous retrievals were performed of aerosol parameters (extinction profiles, aerosol optical thickness), ozone $\left(\mathrm{O}_{3}\right)$, formaldehyde $(\mathrm{HCHO})$, glyoxal (CHOCHO), sulphur dioxide $\left(\mathrm{SO}_{2}\right)$, and water vapour $\left(\mathrm{H}_{2} \mathrm{O}\right)$. Together with the permanent measurement capability at the Cabauw site (see Sect. 2.2), characterizing the meteorological state of the atmosphere, the CINDI campaign thus provided a comprehensive observational data set of atmospheric constituents in a highly polluted region of the world during summertime.

The paper is organized as follows. In Sect. 2 we describe the campaign design, participating instruments, and the setup of the experiments. In Sect. 3 we describe the meteorological and air pollution conditions, the data collected and the measurement characteristics. Early results of the campaign are presented in Sect. 4, and Sect. 5 discusses the potential of this unique data set for future studies. The conclusions are given in Sect. 6.

\section{Campaign design}

\subsection{Seasonal timing}

The early summer timing of CINDI was motivated by several reasons. Summer is the season with mo 60, 170, and 100 for winter, spring, and autumn, respectively), increasing the probability of cloud-free skies needed for favourable ground-based and satellite retrievals. During summer, convection leads to well-mixed and relatively deep boundary layers with $\mathrm{NO}_{2}$ concentrations that can be well-detected by both MAX-DOAS and satellite instruments. A disadvantage of having an $\mathrm{NO}_{2}$ measurement campaign in summer, is that $\mathrm{NO}_{\mathrm{x}}$ emissions are generally lower than in winter, and the average lifetime of $\mathrm{NO}_{2}$ is shorter. In late summer the increased convective activity more often leads to cumulus clouds and even thunderstorms, obstructing remote sensing observations of $\mathrm{NO}_{2}$. In winter, when $\mathrm{NO}_{2}$ is mostly confined within a shallow boundary layer, lifting to the free troposphere is suppressed. This, in combination with the low solar elevation angles in the winter, would lead to more challenging circumstances, in particular for satellite retrievals.

\subsection{Description of the CESAR site}

The CESAR site is located at latitude $51.971^{\circ} \mathrm{N}$, longitude $4.927^{\circ} \mathrm{E}$, at about $0.7 \mathrm{~m}$ below sea level in an extended and flat polder landscape as indicated in Fig. 1 (left image). The Cabauw site was chosen because of its unobstructed view close to the horizon, its large day-to-day variability in tropospheric nitrogen dioxide and aerosols enabling the sampling of a wide range of pollution conditions, the absence of local pollution sources, the $213 \mathrm{~m}$ tower as depicted in Fig. 1, from which the planetary boundary layer can be sampled at various altitudes, and the excellent local support. The same site has been used for two previous more exploratory campaigns focusing on the validation of satellite observations (Brinksma et al., 2008; Hains et al., 2010). Cabauw is a rural site, with only a few pollution sources nearby. However, the wider vicinity is densely populated, with the city of Utrecht and a dense highway grid within $25 \mathrm{~km}$, so that the site experiences recurring pollution events such as from the daily morning and afternoon rush hours. In addition, Cabauw is influenced by the transport of air pollution from emission sources further away, as shown in the June-July average tropospheric $\mathrm{NO}_{2}$ column retrieved from OMI (see Fig. 2). Northerly winds generally carry relatively clean air from the sea, but winds from any other direction are likely to result in the sampling of polluted air. For winds from the west to south-west, Cabauw is downwind of Rotterdam $(40 \mathrm{~km})$, Europe's largest harbour and location of petrochemical plants. Inflow from the south to south-east carries pollution from the southern parts of the Netherlands, Belgium, and the industrialized German Ruhr area (140 to $190 \mathrm{~km})$. 

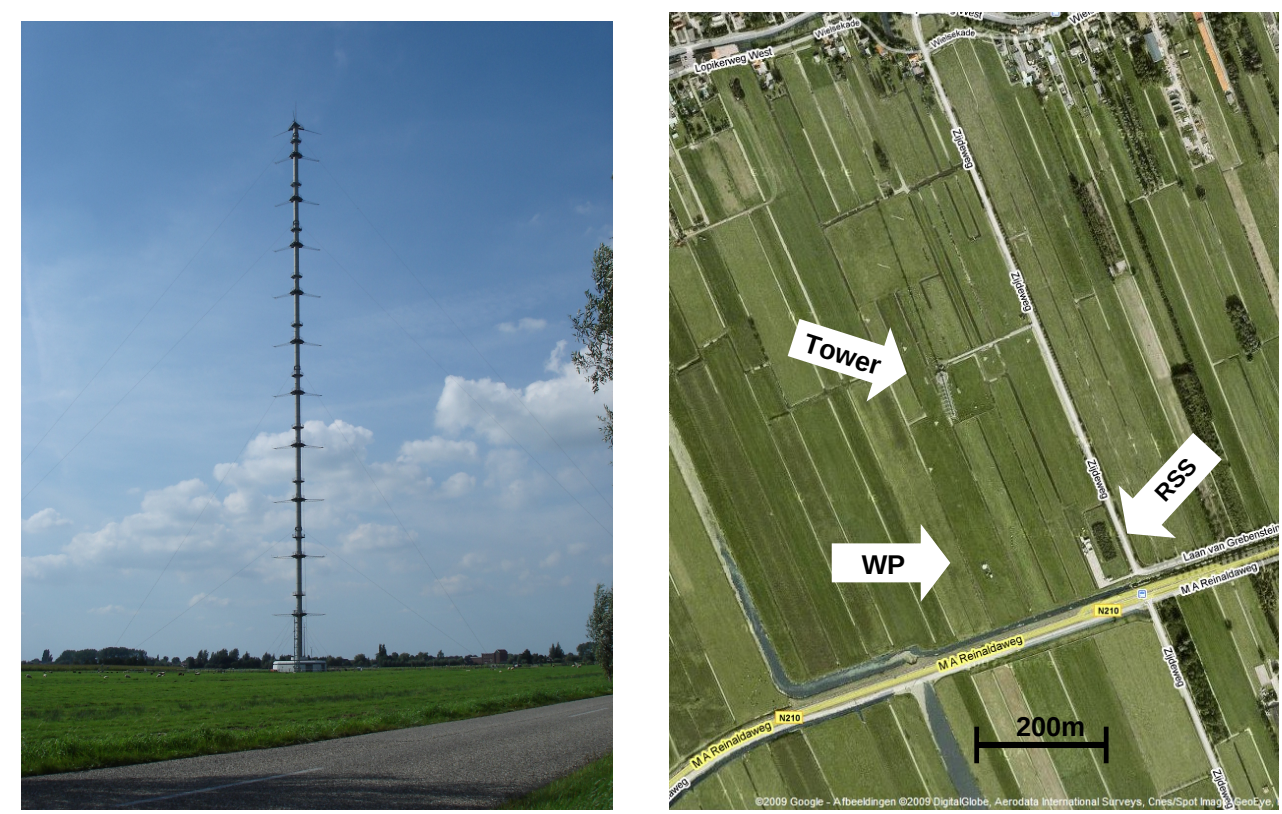

Fig. 1. Left panel: the $213 \mathrm{~m}$ tall meteorological tower at the CESAR site, Cabauw, The Netherlands (source: Wikipedia, http://nl.wikipedia. org/wiki/Meetmast_Cabauw). Right panel: aerial view of the CESAR site at Cabauw depicting the grassland polder landscape, a nearby village to the North, and a local secondary road to the South. Here "RSS" indicates the remote sensing site and "WP" the wind profiler site. Image orientation is north-south hence nearby "Zijdeweg" runs at $23^{\circ}$ away from due north. Depicted area measures $900 \times 1100 \mathrm{~m}^{2}($ source: Google Maps, http://maps.google.nl).

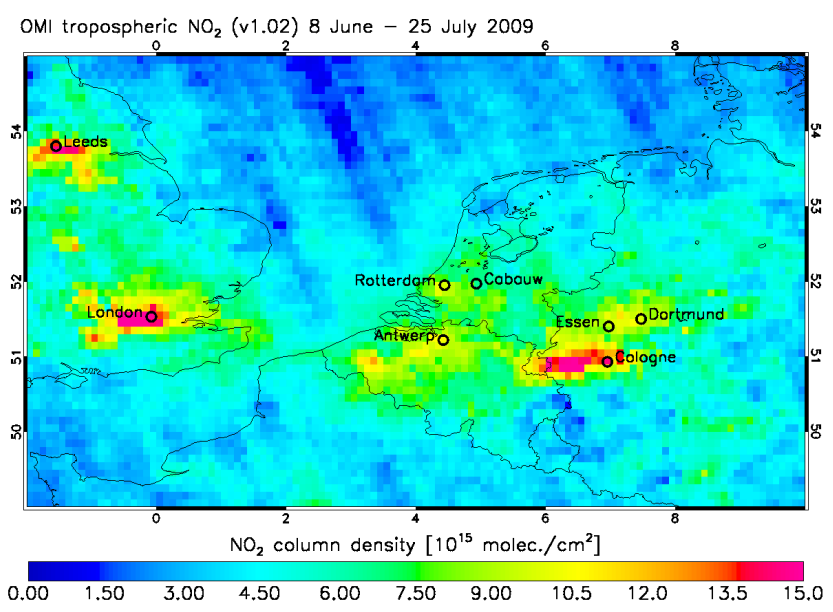

Fig. 2. Average tropospheric vertical $\mathrm{NO}_{2}$ column during CINDI (between 8 June and 25 July 2009) as measured by OMI (DOMINO v1.02). The campaign site Cabauw is located almost in the middle of the Netherlands. Nearby pollution sources are the harbours of Rotterdam $(40 \mathrm{~km})$ and Antwerp (Belgium, $90 \mathrm{~km})$ and the industrial Ruhr area in Germany (140 to $190 \mathrm{~km})$.

The three measurement locations at the CESAR site, used for CINDI, are shown in Fig. 1 (right image). At the remote sensing site (RSS) most of the MAX-DOAS and direct-sun instruments and the lidar systems were deployed. The nearby wind profiler site (WP) provided extra room for several
MAX-DOAS instruments and additional zenith-sky viewing systems. The tower housed all the in-situ sensors taking in air at ground and elevated levels, and had MAX-DOAS and zenith-sky instruments and in-situ systems installed at various altitudes.

\subsection{Participating instruments}

The principal instruments that participated in CINDI, their location on site and relevant specifications are summarized in Tables 1 and 2. Detailed instrument descriptions are given in Appendix A.

More than 20 optical spectrometers originating from 14 international research institutes took part in the field campaign and measured spectra of scattered sunlight from the ground for 4 to 7 weeks. From these spectra, slant columns of nitrogen dioxide and several other species (see Sect. 3.3) were derived by means of the differential optical absorption spectroscopy technique (DOAS, Platt, 1994). Slant columns of $\mathrm{NO}_{2}$ and the oxygen dimer $\left(\mathrm{O}_{2}-\mathrm{O}_{2}\right)$ were compared in a formal semi-blind comparison, following NDACC criteria (Roscoe et al., 2010). Most of the instruments were MAXDOAS systems, capable of performing scans in elevation and sometimes azimuth while measuring scattered sunlight (see for example Hönninger et al., 2004; Wittrock et al., 2004; Clémer et al., 2010). One of the National Aeronautics and Space Administration (NASA) instruments was direct-sun viewing only, and the French National Center for Scientific 


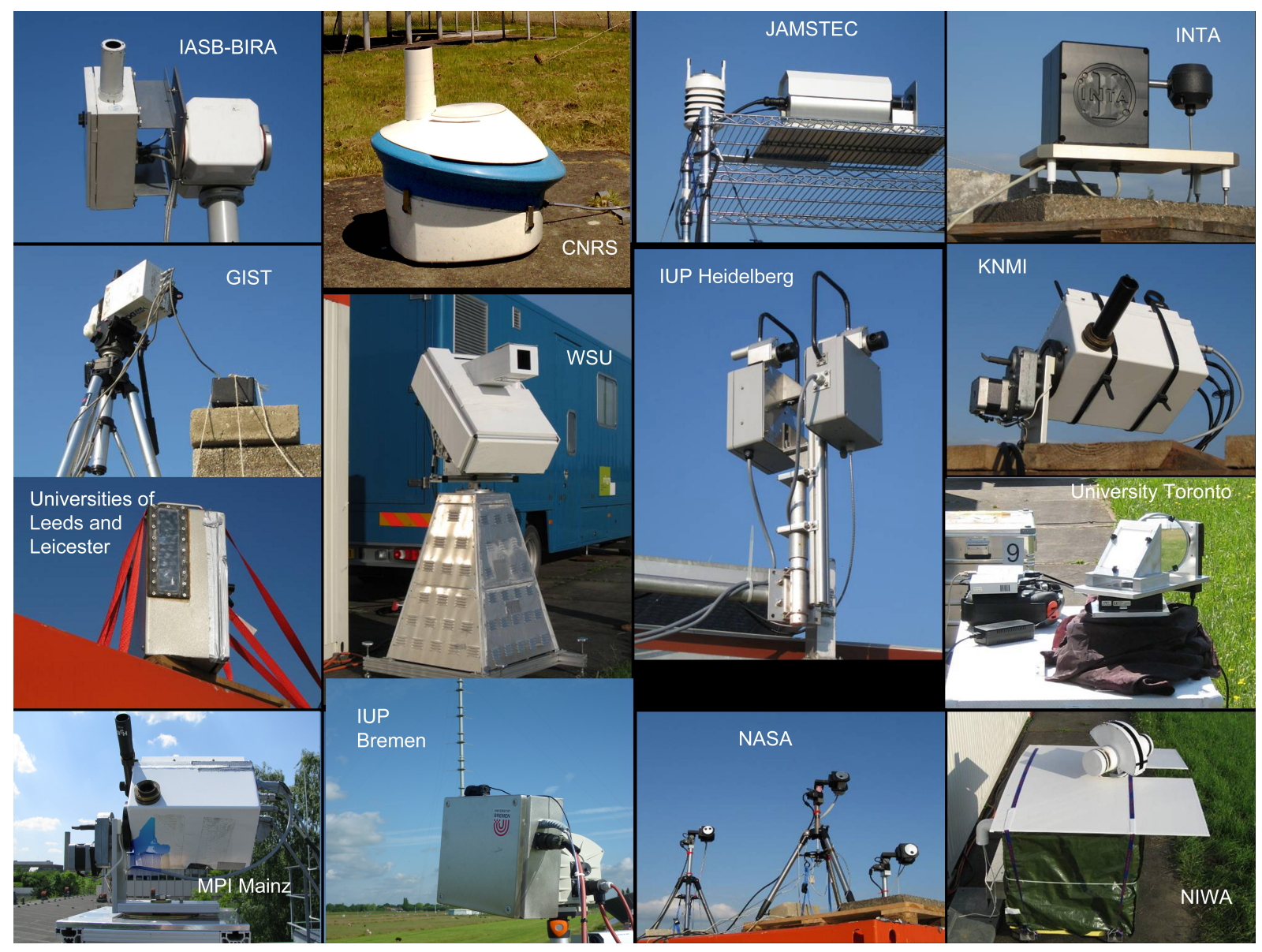

Fig. 3. Snapshots of the various optical instruments installed at the remote sensing site indicating the large variety of optical detection system designs actively involved in the campaign effort. Some images display complete stand-alone systems (e.g. WSU), others are only displaying the telescopes (e.g. NASA) that are connected to the spectrographs and detection systems by optical quartz fibres.

Research (CNRS) Systeme d'Analyse par Observation Zenitale (SAOZ) systems were zenith-viewing only. An illustrative collection of images is shown in Fig. 3, highlighting the tremendous variety in the design of the optical detection systems.

Most optical spectrometers deployed during CINDI consist of three basic components; the entrance optics, the spectrometer and the detector. Figure 4 summarises the layout and viewing geometry of these instruments. The entrance optics includes a telescope that defines the Field of View (FOV). It is often mounted on a motorized mechanical tracker. The telescope is connected to the spectrometer by means of quartz fibre bundles. The spectrometer subsequently separates the incoming light as a function of wavelength, and projects it on the detector. The spectrometer and detector are often housed in the same unit. Exceptions to this description are the WSU, University of Toronto, and NIWA systems, and the six "mini-MAX-DOAS" instruments (commercially available all-in-one systems). The entire WSU system is mounted on a sun-tracker, the stationary
NIWA system contains an optical directional scanner internally, and the stationary system of the University of Toronto can switch between zenith and MAX-DOAS functionality by having an optical scanner fitted to its zenith entrance port. The telescope of the mini-MAX-DOAS systems is attached to the instrument and the complete instrument is mounted on a stepper-motor. All systems are different in terms of FOV, spectral range and resolution, see Table 1.

The RIVM nitrogen dioxide lidar with elevation scanning and operating from a mobile truck provided vertical profiles of nitrogen dioxide at moderate resolution (Volten et al., 2009). The Raman lidar Caeli provided vertical profiles of aerosol optical properties, backscatter at three wavelengths and extinction at two wavelengths (Apituley et al., 2009). Additional in-situ nitrogen dioxide instruments equipped with photolytic converters (Kley and McFarland, 1980) were operated on the ground and on the various tower platforms. A novel balloon-borne nitrogen dioxide sonde developed by KNMI (Sluis et al., 2010) was flown for the first time, providing in-situ measurements of $\mathrm{NO}_{2}$ at high vertical resolution. 


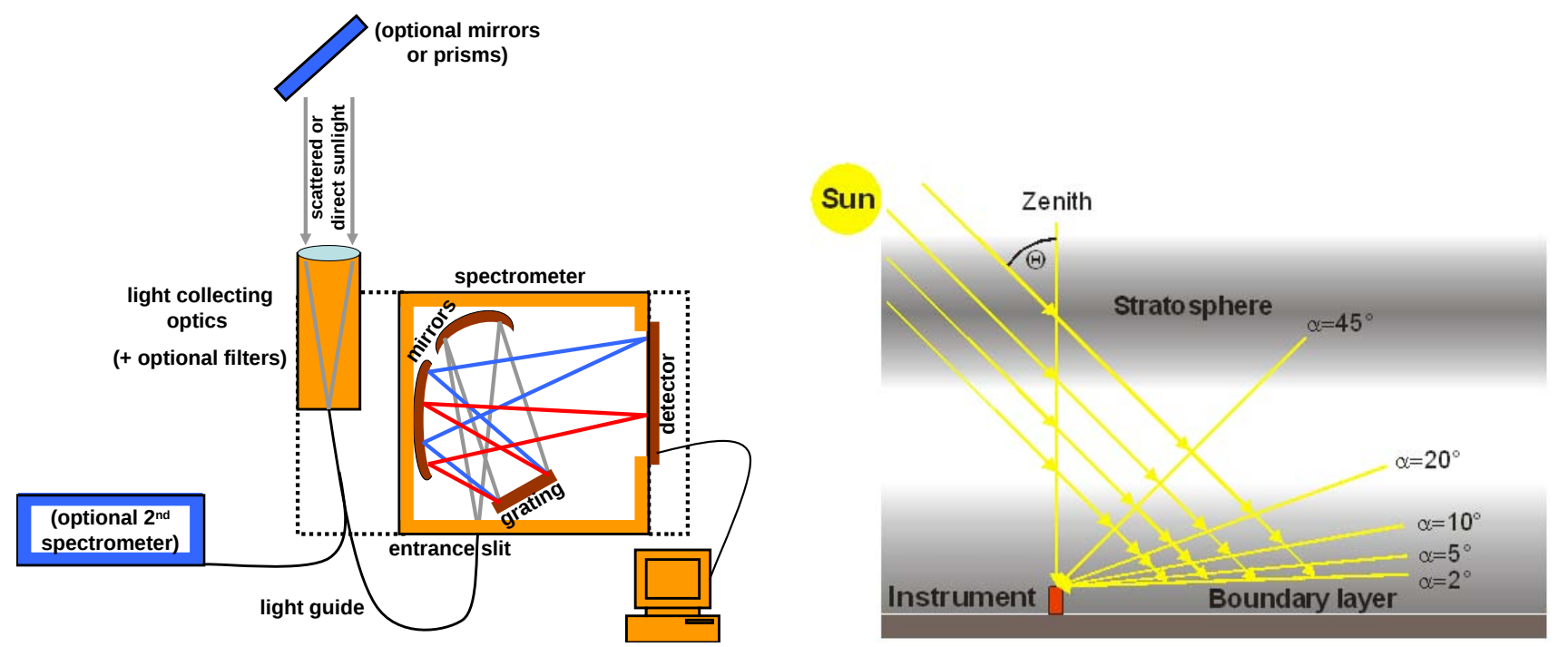

Fig. 4. Left panel: MAX-DOAS instrument layout. The dashed box indicates that the three components (optics, spectrometer, detector) can be separate units or included in the same housing. Right panel: MAX-DOAS viewing geometry. The participating MAX-DOAS instruments measured at different elevation angles consecutively; tropospheric information can be retrieved using the fact that the light path through the stratosphere is almost constant as a function of elevation angle. The scanning is performed by rotating either a mirror or prism, or the optical head or telescope, or the whole instrument.

Ozone was measured with an ozone lidar (Hoexum et al., 2009; Apituley et al., 2010) located in Bilthoven (30 km from the site) and by ozone sondes launched from the CESAR site.

TNO continuously performs aerosol observations in the basement of the tower where air is sampled via a common inlet at $60 \mathrm{~m}$. A multi-angle absorption photometer (MAAP) was used to quantify the aerosol absorption coefficient. An integrating nephelometer was used for the (back-) scattering coefficient. To increase comparability between observations in (global) aerosol networks (WMO/GAW guidelines, 2003) prescribe that sampled aerosol is dried to relative humidities below $40 \%$. Aerosol optical properties, most notably the scattering coefficient, strongly increase with increasing relative humidity; thus drying frustrates comparison to aerosol optical properties measured at ambient conditions, e.g. remotely sensed aerosol properties. To overcome this issue, Paul Scherrer Institute (PSI) operated a humidified nephelometer that measures the aerosol (back-)scattering coefficient at defined relative humidities between 20 and $95 \%$.

The placement of the instruments over the campaign site was driven by various requirements. The most important of which was the accessibility of all desired viewing angles while avoiding mutual visual obstructions by the telescopes. Many receivers were deployed on the roof tops of four containers or on the concrete surface next to them with most of the spectrometers inside. The roof-top deployment provided an extra $3.5 \mathrm{~m}$ of altitude hence overlooking most of the low vegetation. The second requirement was the need for taking observations at higher altitudes which were performed from the tower platforms by both in-situ and remote sensing systems.
In order to meet the power needs for all participating instruments, an additional electrical power generator was installed at the site. We chose to install a $100 \mathrm{~kW}$ diesel-driven generator at a fair distance from the telescopes $(30 \mathrm{~m})$ and in such an orientation that its exhaust gases were transported away from the site by the most frequently occurring wind directions (south-west to west). The nominal load on the generator was around $20 \%$ of its maximum output allowing the brand-new diesel engine to run smoothly and efficiently. During the campaign no sign of contamination of the in-situ and remote sensing observations by the generator exhaust gases has been reported.

\subsection{Ancillary observations}

In support of the systems temporarily deployed at the site for the campaign purpose as described in Sect. 2.3, the CESAR site at Cabauw is equipped with a large suite of instruments for continuous monitoring and characterization of the state of the atmosphere. Standardized systems record the surface $(2 \mathrm{~m})$ level temperature, pressure, visibility, wind direction and speed, and humidity. The KNMI-tower at Cabauw was originally built for meteorological research to establish relations between the state of the planetary boundary layer (PBL), the land surface conditions and the general weather situation for all seasons. It also supports aviation at Schiphol Airport. Hence the tower has wind, pressure and temperature instruments installed at various levels. Nitrogen dioxide and aerosols are routinely sampled close to the base of the tower by in-situ instruments as part of the national air quality network (LML) and the CESAR partnership. The 
Table 1. Overview of CINDI participating spectrometers. "MMD" means Mini-MAX-DOAS (Appendix A). Columns denote: institute, field of view, spectral range and spectral resolution, coupling between telescope and spectrometer (F: multimode fibre, D: direct coupling, L: liquid light guide), type of detector, detector temperature and site location (RSS: remote sensing site, Twr: tower, WP: wind profiler site, M: mobile). Other details are given in Appendix A.

\begin{tabular}{|c|c|c|c|c|c|c|c|}
\hline Institute/instrument & $\mathrm{FOV}\left({ }^{\circ}\right)$ & range $(\mathrm{nm})$ & res $(\mathrm{nm})$ & Coupl. & Det. & $T\left({ }^{\circ} \mathrm{C}\right)$ & Loc. \\
\hline BIRA-IASB D. Channel & 0.8 & $\begin{array}{l}300-388 \\
400-700\end{array}$ & $\begin{array}{l}0.37 \\
0.95\end{array}$ & $\begin{array}{l}F \\
F\end{array}$ & $\begin{array}{l}\text { CCD } \\
\text { CCD }\end{array}$ & $\begin{array}{l}-30 \\
-30\end{array}$ & RSS \\
\hline BIRA-IASB MMD & 0.6 & $290-433$ & 0.6 & $\mathrm{D}$ & LinArr & +15 & Twr \\
\hline BIRA-IASB mobile & 2.5 & $270-500$ & 1.15 & $\mathrm{~F}$ & LinArr & $\mathrm{n} / \mathrm{a}$ & M \\
\hline IUP-Bremen D. Channel & 1.2 & $\begin{array}{l}315-384 \\
401-573\end{array}$ & $\begin{array}{l}0.4 \\
0.8\end{array}$ & $\begin{array}{l}F \\
F\end{array}$ & $\begin{array}{l}\text { CCD } \\
\text { CCD }\end{array}$ & $\begin{array}{l}-35 \\
-35\end{array}$ & RSS \\
\hline CNRS SAOZ & 9.0 & $270-630$ & 1.1 & $\mathrm{D}$ & LinArr & $\mathrm{n} / \mathrm{a}$ & WP \\
\hline CNRS mobile & 9.0 & $270-630$ & 1.1 & $\mathrm{D}$ & LinArr & $\mathrm{n} / \mathrm{a}$ & M \\
\hline CNRS mini-SAOZ & 6.0 & $270-800$ & 0.6 & $\mathrm{D}$ & $\mathrm{CCD}$ & $\mathrm{n} / \mathrm{a}$ & Twr \\
\hline GIST MMD UV & 0.5 & $290-430$ & 0.7 & $\mathrm{~F}$ & LinArr & -5 & RSS \\
\hline IUP-Heidelberg DOAS 1 & 0.9 & $290-790^{1}$ & 0.6 & $\mathrm{~F}$ & LinArr & +10 & WP \\
\hline IUP-Heidelberg DOAS 2 & 0.9 & $320-465$ & 0.45 & $\mathrm{~F}$ & $\mathrm{CCD}$ & -30 & WP \\
\hline INTA NEVA-II & 1.0 & $387-514$ & 0.6 & $\mathrm{~F}$ & CCD & -40 & RSS \\
\hline INTA RASAS-II & 1.0 & $393-510^{2}$ & 0.45 & $\mathrm{~F}$ & $\mathrm{CCD}$ & -30 & RSS \\
\hline JAMSTEC & $<1.0$ & $223-558$ & 0.7 & $\mathrm{~F}$ & LinArr & +40 & RSS \\
\hline KNMI MMD UV & 0.45 & $290-433$ & 0.6 & $\mathrm{D}$ & LinArr & $\mathrm{n} / \mathrm{a}$ & Twr \\
\hline KNMI MMD VIS & 0.4 & $400-600$ & 0.5 & $\mathrm{D}$ & LinArr & $\mathrm{n} / \mathrm{a}$ & RSS \\
\hline Univs Leicester\&Leeds & 1.0 & $425-490$ & 0.54 & $\mathrm{~F}$ & CCD & -42 & RSS \\
\hline MPIC-Mainz MMD & 1.2 & $310-461$ & 0.6 & $\mathrm{D}$ & LinArr & -4 & Twr \\
\hline MPIC-Mainz mobile & 1.2 & $320-466$ & $0.45-0.85$ & $\mathrm{D}$ & LinArr & -4 & M \\
\hline NASA PANDORA $(2,3,9)$ & 1.6 & $280-530$ & 0.6 & $\mathrm{~F}$ & CCD & +10 & RSS \\
\hline NIWA & 0.5 & $389-510$ & 0.48 & $\mathrm{~F}$ & $\mathrm{CCD}$ & -20 & RSS \\
\hline Univ. Toronto & 2.0 & $\begin{array}{l}341-545 \\
315-380\end{array}$ & $\begin{array}{l}0.5-2.5 \\
0.2-0.8\end{array}$ & $\mathrm{~L}$ & $\mathrm{CCD}$ & -72 & RSS \\
\hline WSU MF-DOAS & 1.4 & $282-498$ & 0.83 & $\mathrm{D}$ & $\mathrm{CCD}$ & -70 & RSS \\
\hline
\end{tabular}

Notes: ${ }^{1}$ IUP Heidelberg connects three MAX-DOAS spectrometers to one fibre input to cover this large wavelength range; ${ }^{2}$ after 6 July: $325-440 \mathrm{~nm}$.

wind profiling radar determines winds throughout the lower troposphere. A Vaisala LD-40 Ceilometer operates continuously to determine the cloud-base altitude and the PBL height. RIVM operated a backscatter lidar providing information on cloud structures and aerosol layers overhead up to $15 \mathrm{~km}$ at $5 \mathrm{~min}$ resolution. Finally, the total sky imager (TSI) operates continuously at the site generating hemispherical images of the cloud structures overhead at a 1 min interval that are analysed for total cloud cover. The CESAR site at Cabauw hosts a certified BSRN (Baseline Surface Radiation Network) and AERONET (AErosol RObotic NETwork) site that completes the suite of instruments and observations to characterize the state of the atmosphere. The BSRN instruments monitor direct, diffuse, global and downward short-wave and long-wave radiative components (Ohmura et al., 1998). AERONET is a network of ground-based sun photometers which measure atmospheric aerosol properties (Holben et al., 1998).

\subsection{Set-up of the experiments}

\subsubsection{Viewing in the same direction}

In the first month of the campaign, between 8 June and 8 July, all MAX-DOAS spectrometers and the $\mathrm{NO}_{2}$ lidar scanned at different elevation angles along the same westnorth-westerly direction, around $287^{\circ}$. In this direction all instruments had an unobstructed view down to $0.5^{\circ}$ elevation angle. For the instruments at the RSS this azimuth direction was determined by a fixed point on the horizon at about $1.2 \mathrm{~km}$ distance. The spread in the locations of the instruments at the RSS results in a spread in the viewing directions of about $1^{\circ}$, which is within the FOV of most of the systems. 
Table 2. Other CINDI participating instruments, measuring $\mathrm{NO}_{2}$, ozone, and aerosol. Site locations are RSS: remote sensing site, Twr: tower, WP: wind profiler site. Other details are given in Appendix A.

\begin{tabular}{|c|c|c|c|}
\hline Institute & Instrument & Measured parameter & Location \\
\hline RIVM & $\mathrm{NO}_{2}$ lidar & $\mathrm{NO}_{2}$ profile & RSS \\
\hline RIVM & $\mathrm{NO}_{\mathrm{x}}$ analysers with photolytic converter & $\mathrm{NO}, \mathrm{NO}_{2}$ concentration & $\operatorname{Twr}(3 \mathrm{~m} / 100 \mathrm{~m}), \operatorname{Twr}(200 \mathrm{~m})$ \\
\hline RIVM & Tropospheric $\mathrm{O}_{3}$ lidar (DIAL) & $\mathrm{O}_{3}$ profile & Bilthoven $(\sim 30 \mathrm{~km} \mathrm{NE})$ \\
\hline RIVM & Caeli lidar & Profiles of aerosol, water vapour and clouds & RSS \\
\hline RIVM & Backscatter lidar & Backscatter profile & RSS \\
\hline KNMI & $\mathrm{NO}_{2}$ sondes & $\mathrm{NO}_{2}$ profile & Twr \\
\hline KNMI & $\mathrm{O}_{3}$ sondes & $\mathrm{O}_{3}$ profile & Twr \\
\hline IUP Bremen & $\mathrm{NO}_{\mathrm{x}}$ analyser with photolytic converter & $\mathrm{NO}, \mathrm{NO}_{2}$ concentration & Twr (3 m) \\
\hline EMPA & $\mathrm{NO}_{\mathrm{x}}$ analyser with photolytic converter & $\mathrm{NO}, \mathrm{NO}_{2}$ concentration & Twr $(3 \mathrm{~m})$ \\
\hline RIVM/LML & $\mathrm{NO}_{\mathrm{x}}$ analyser with molybdenum converter & $\mathrm{NO}, \mathrm{NO}_{2}$ concentrations & Twr (3 m) \\
\hline PSI & Humidified nephelometer (WetNeph) & aerosol (back-)scattering coefficient (RH-dependence) & Twr \\
\hline TNO & SMPS/APS & particle size distribution $0.01-10 \mu \mathrm{m}$ & Twr \\
\hline TNO & MAAP & absorption coefficient & Twr \\
\hline TNO & Nephelometer & aerosol (back-)scattering coefficient & Twr \\
\hline
\end{tabular}

The instruments at the tower scanned at a fixed azimuth direction around $286^{\circ}$, so that they viewed approximately the same air mass as the systems at the RSS. The MAX-DOAS instruments had a minimum set of prescribed elevation angles, and each vertical scan had to be obtained within $30 \mathrm{~min}$. All instruments viewed in zenith direction in a 30-min window around noon. Calibration of the zero degree elevation angle was the subject of particular attention in the early phase of the campaign. Roscoe et al. (2010) pointed out that this calibration is crucial for the interpretation of the data, especially for the lower elevation angles, since the air mass factors at low elevation angles change considerably with small changes in elevation angle.

\subsubsection{Viewing in different directions and at different locations}

In the second part of the campaign, 9 July to 26 July, the viewing directions of some of the MAX-DOAS instruments and the $\mathrm{NO}_{2}$ lidar were changed in order to study (i) the consistency of air mass factor calculations and (ii) the spatial variability of $\mathrm{NO}_{2}$. The azimuth positions for this period are listed in Table 3. The MAX-DOAS instruments from BIRA-IASB and IUP Bremen and the $\mathrm{NO}_{2}$ lidar from RIVM scanned several azimuthal directions quasi-simultaneously. In addition the three mobile systems were mounted on a car and driven around Cabauw on several tours. One of these tours, driven by the MPIC Mainz car, is shown in Fig. 5. This figure also indicates the large variability in tropospheric $\mathrm{NO}_{2}$ columns along the route. On 15 and 16 July the $\mathrm{NO}_{2}$ lidar truck was placed at $2.1 \mathrm{~km}$ distance viewing into the direction of the tower towards the three in-situ instruments in order to verify the $\mathrm{NO}_{2}$ concentration measured by the lidar.

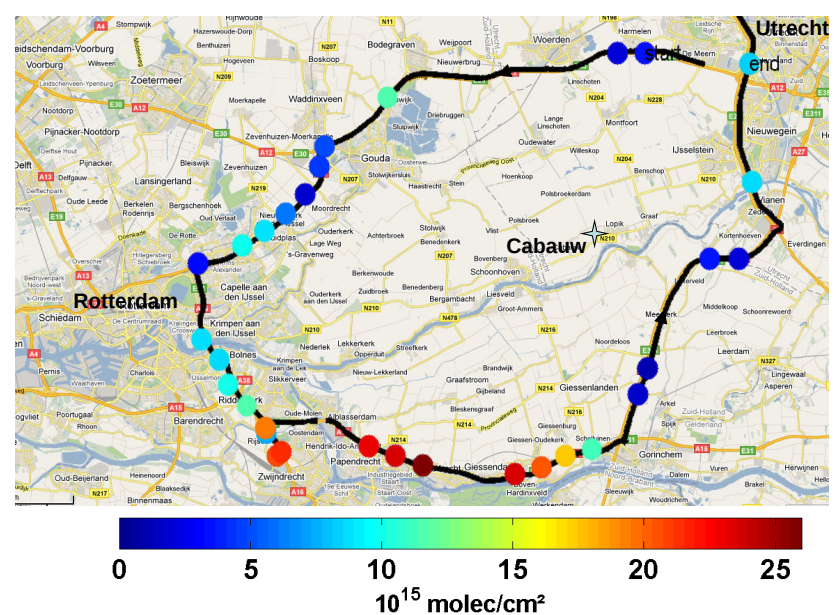

Fig. 5. Mobile measurements around Cabauw with the mini-MAXDOAS instrument of MPIC Mainz in the morning of 12 June. The wind was coming from west to north-west, with a speed of $4.5 \mathrm{~m} \mathrm{~s}^{-1}$. The track displayed runs (anticlockwise) over major highways. The colours indicate measured tropospheric vertical $\mathrm{NO}_{2}$ columns.

\subsubsection{Observing from different altitudes}

The zenith-viewing mini-SAOZ instrument (Sect. 2.3) was located at the $213 \mathrm{~m}$ altitude level during the entire campaign. When combining the measurements with the SAOZ instrument at the ground, the partial column between 0 and $213 \mathrm{~m}$ can be derived.

During the first part of the campaign, three of the in-situ monitors with photolytic converters (Sect. 2.3) were placed close by the regular on-site in-situ monitor with molybdenum converter, in order to be able to investigate the biases between these instruments. One of the RIVM monitors with 
Table 3. Instruments participating in the experiment with multiple azimuthal viewing directions.

\begin{tabular}{lll}
\hline Instrument & Viewing directions & Period \\
\hline IUP-Bremen VIS & $17^{\circ}, 62^{\circ}, 152^{\circ}, 197^{\circ}, 242^{\circ}, 287^{\circ}, 332^{\circ}$ & 12 June-21 July \\
BIRA-IASB VIS & $45^{\circ}, 90^{\circ}, 135^{\circ}, 180^{\circ}, 225^{\circ}, 270^{\circ}, 315^{\circ}, 358^{\circ}$ & $10-22 \mathrm{July}$ \\
NASA P2 & $66^{\circ}$ & $14-20 \mathrm{July}$ \\
NASA P3 & $187^{\circ}$ & $14-20 \mathrm{July}$ \\
KNMI VIS & $253^{\circ}$ & $10-31 \mathrm{July}$ \\
INTA NEVA & $287^{\circ}$ & $28 \mathrm{June}-21 \mathrm{July}$ \\
Univ. Toronto & $287^{\circ}$ & $10-17 \mathrm{July}$ \\
JAMSTEC & $287^{\circ}$ & $9 \mathrm{June}-24 \mathrm{July}$ \\
Univs. of Leicester \& Leeds & $326^{\circ}$ & $10-22 \mathrm{July}$ \\
$\mathrm{NO}_{2}$ lidar & $224^{\circ}, 233^{\circ}, 242^{\circ}, 251^{\circ}, 260^{\circ}, 269^{\circ}, 278^{\circ}, 287^{\circ}, 288^{\circ}, 296^{\circ}, 305^{\circ}, 314^{\circ}$ & $9-22 \mathrm{July}$ \\
\hline
\end{tabular}
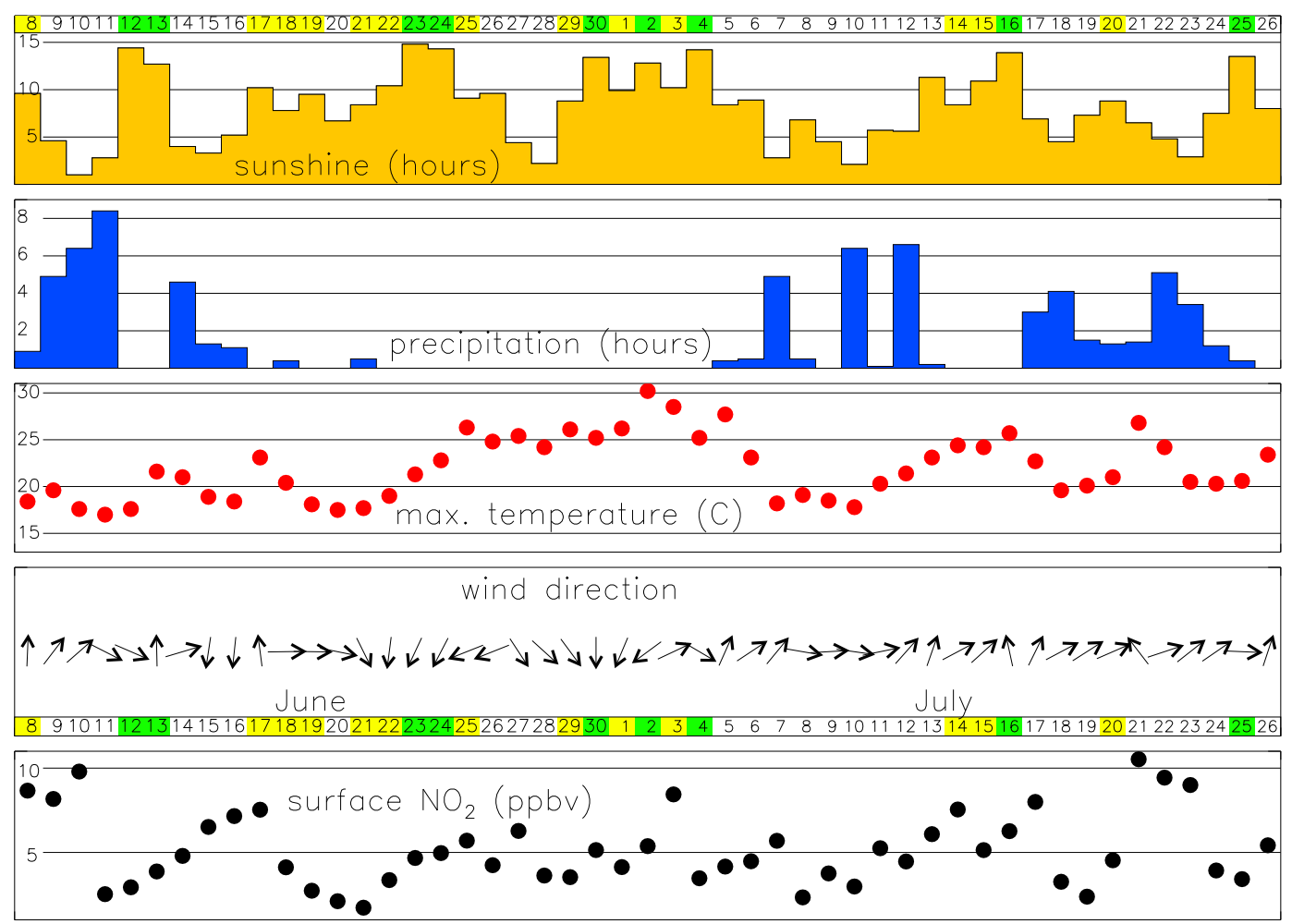

Fig. 6. Overview of meteorological conditions during the CINDI campaign period. From top to bottom: hours of sunshine, hours of precipitation, daily maximum temperature, wind direction (pointing up means winds coming from the south), and average daytime surface level $\mathrm{NO}_{2}$ derived from the in-situ instruments of RIVM, IUP Bremen and EMPA. Category A days (see text) are coloured green, category B days are coloured yellow.

photolytic converter was placed at $200 \mathrm{~m}$ during the entire campaign. In the second part of the campaign the other RIVM monitor with photolytic converter was placed at the $100 \mathrm{~m}$ level.

The three mini-MAX-DOAS instruments at the tower were at $20 \mathrm{~m}$ during the first part of the campaign, and later displaced at different altitude levels in order to study the consistency of the column and profile retrievals for different altitudes. A fourth mini-MAX-DOAS instrument was placed at $20 \mathrm{~m}$ in the tower, viewing in the opposite direction.

\section{Campaign execution}

\subsection{Meteorological conditions during CINDI}

June and July 2009 were relatively warm and sunny in the Netherlands. These months were $0.5^{\circ} \mathrm{C}$ warmer and had $24 \%$ more sun hours than the long-term average (1971$2000)$ at Cabauw. The number of sun hours, maximum surface temperature, precipitation and wind direction for the campaign period are shown in Fig. 6. More details are given 
in Appendix B. During CINDI, there were 9 days with 10 or more sunny hours, where a sunny hour is defined as an hour with less than $50 \%$ cloud cover and with more than $0.5 \mathrm{~h}$ sunshine: 12, 13, 23, 24, and 30 June, and 2, 4, 16, and 25 July. These days were most suitable for retrievals from groundbased and satellite remote sensing observations over Cabauw. During these "category A" days (green in Fig. 6), the wind was more frequently coming from northerly directions, compared to prevailing south-westerly winds during the rest of the campaign. Thirteen days (yellow in Fig. 6) had between 4 and 9 sunny hours. During these "category B" days the wind was most frequently coming from south-westerly directions.

\subsection{Air pollution during CINDI}

Figure 2 shows average tropospheric $\mathrm{NO}_{2}$ columns observed from OMI over north-western Europe during the CINDI campaign (based on Boersma et al., 2007). We see that Cabauw is adjacent to strong sources of pollution in the west (Rotterdam), the south (industrial Flanders), and the south-east (German Ruhr Area), but that regions north of Cabauw are relatively clean. Surface $\mathrm{NO}_{2}$ concentrations at Cabauw measured with in-situ techniques show considerable day-to-day variation during CINDI, with generally lowest $\mathrm{NO}_{2}$ concentrations ( 2 to 4 ppbv) on days with precipitation, cloudiness, or prevailing northerly winds (see Figs. 6 and 7). On "category A" days, with sunny conditions, observed surface $\mathrm{NO}_{2}$ concentrations range from 4 to $10 \mathrm{ppbv}$. Figure 8 illustrates that the variability in $\mathrm{NO}_{2}$ levels on sunny days over Cabauw is mostly driven by wind direction. On days with winds from southerly and westerly directions (12 June, 17 June, 3 July, 14-16 July), both OMI retrievals and CHIMERE simulations over Cabauw show tropospheric $\mathrm{NO}_{2}$ columns that are approximately 2 times higher than on days with winds from the clean north-east (24 June, 25 June, 30 June, 1 July). Particularly 3 and 14 July stand out as strongly polluted days at Cabauw, with high concentrations of $\mathrm{NO}_{2}$ (more than $10 \mathrm{ppbv}$ on 14 July when winds were from the polluted Ruhr area in Germany) and HCHO, and secondary pollutants ozone and aerosol (see Fig. 5 in Irie et al., 2011). Enhanced $\mathrm{SO}_{2}$ concentrations (more than $5 \mathrm{ppbv}$, not shown) were sampled on 5, 6 and 14 July (Irie et al., 2011), when the air over Cabauw was predominantly from the nearby North Sea and northern Atlantic. Over these regions, shipping traffic is dense, suggesting that the enhanced $\mathrm{SO}_{2}$ concentrations over Cabauw originated from shipping activity.

Enhanced trace gas concentrations likely originating from biogenic emissions were also observed during CINDI. Episodes with enhanced $\mathrm{HCHO}$ concentrations were observed on several days. For example, on 25 and 26 June, and on 3 July 2009 HCHO concentrations inferred from MAX-DOAS measurements reached 4-8 ppbv. On these days, maximum afternoon temperatures at Cabauw were

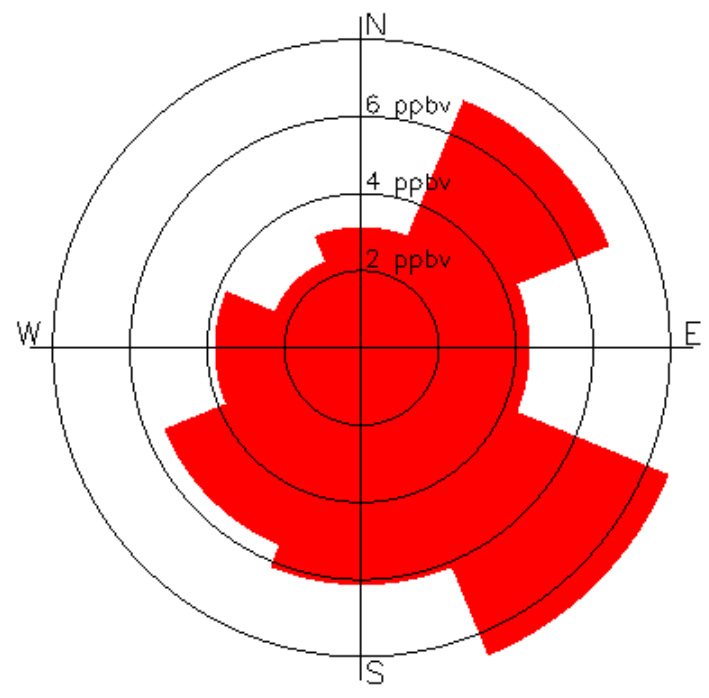

Fig. 7. Average surface $\mathrm{NO}_{2}$ mixing ratio during CINDI as a function of wind direction. Included are data between 06:00 and 18:00 UTC and with wind speed exceeding $1.5 \mathrm{~m} \mathrm{~s}^{-1}$.

between 25 and $30^{\circ} \mathrm{C}$. The strong correlation between HCHO concentrations and ambient temperature at Cabauw reported by Irie et al. (2011) suggests that the enhanced HCHO concentrations observed during CINDI originated from nearby isoprene emissions. Further discussion of the enhanced VOC concentrations, and their relations to sources, is given in Irie et al. (2011).

\subsection{Measurement characteristics}

The following parameters were inferred from the measurements:

- in-situ concentrations of $\mathrm{NO}_{2}$ at different altitudes along the tower;

- slant and vertical columns of tropospheric $\mathrm{NO}_{2}$ with the MAX-DOAS, direct-sun and zenith-sky instruments;

- vertical profiles of $\mathrm{NO}_{2}$ with a lidar and a sonde, and with the MAX-DOAS as inferred from the slant columns at different elevation angles;

- slant columns of other species, like $\mathrm{O}_{4}, \mathrm{HCHO}, \mathrm{SO}_{2}$, $\mathrm{O}_{3}, \mathrm{H}_{2} \mathrm{O}$, and $\mathrm{CHOCHO}$, with some of the MAXDOAS and direct-sun instruments - for some of the trace gases (e.g. HCHO) also vertical columns and profile information have been derived;

- aerosol optical depth with the MAX-DOAS instruments and the AERONET instrument;

- aerosol extinction profiles from Caeli (from first principles), and with the MAX-DOAS (as inferred from the $\mathrm{O}_{4}$ slant columns); 


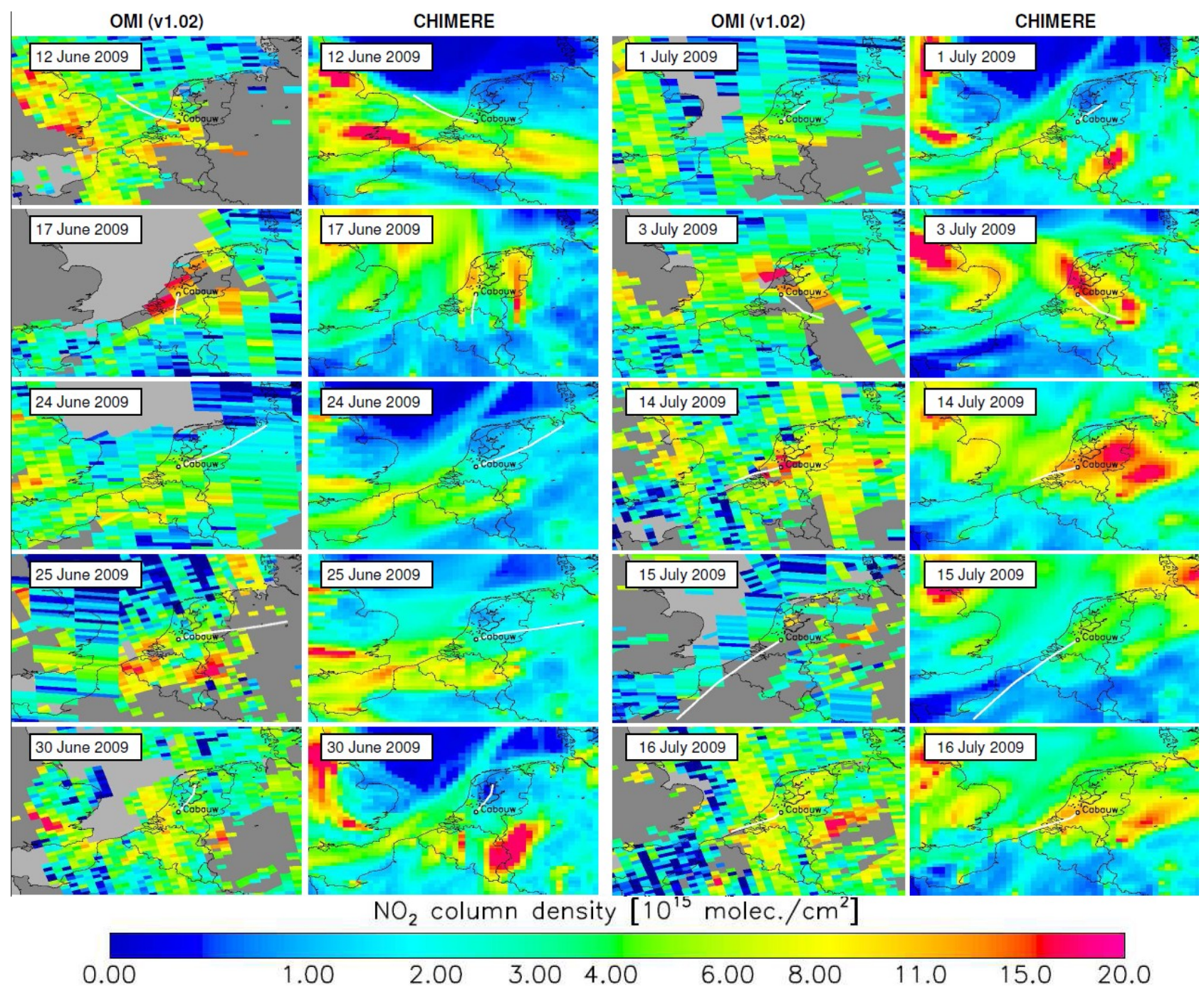

Fig. 8. Tropospheric vertical $\mathrm{NO}_{2}$ columns observed by OMI and simulated by the CHIMERE chemistry transport model on mostly sunny days at Cabauw during CINDI in June (left columns) and July (right columns) 2009. Grey areas in the OMI (DOMINO v1.02) satellite observations generally indicate cloud radiance fractions $>0.5$. The white trajectory shows the path that an air parcel has travelled from 03:00 UTC until arriving at Cabauw at 12:00 UTC (source: http://www.nilu.no/trajectories/modeldata/2009/cabauw). The OMI observations are performed between 11:00 and 14:00 UTC, CHIMERE simulations are shown for 11:30 UTC.

- aerosol extinction at the surface with in-situ (humidified) nephelometers and absorption photometers (MAAP)

- ozone profiles with sondes and an ozone lidar.

Figure 9 gives an overview of when the measurements were performed, detailed per instrument type. The $\mathrm{NO}_{2}$ in-situ instruments from IUP Bremen, EMPA and RIVM measured almost continuously from 12 June to 10 July, with one instrument at $200 \mathrm{~m}$ altitude and the rest at $3 \mathrm{~m}$ altitude. After 3 July the EMPA instrument left, and from 10 July onwards one of the in-situ instruments was placed at the $100 \mathrm{~m}$ level, so that the concentrations at three different levels were measured simultaneously (see Fig. 10). The in-situ instruments were the only instruments measuring during night and day. The majority of the MAX-DOAS instruments took measurements between 13 June and 21 July. Slant column densities were derived for the whole period with an estimated precision of 5-10\% for most trace gases (see Roscoe et al., 2010; Pinardi et al., 2012).

From the slant columns the tropospheric column amounts and some information on vertical profiles can be derived (Hönninger et al., 2004; Wittrock et al., 2004). Different retrieval methods have been proposed and tested to convert slant column densities to vertical column densities and onward to vertical profiles. These methods are subject to intercomparison as briefly described in Sects. 4.3 and 4.4 and in more detail in Wittrock et al. (2012). All such methods 


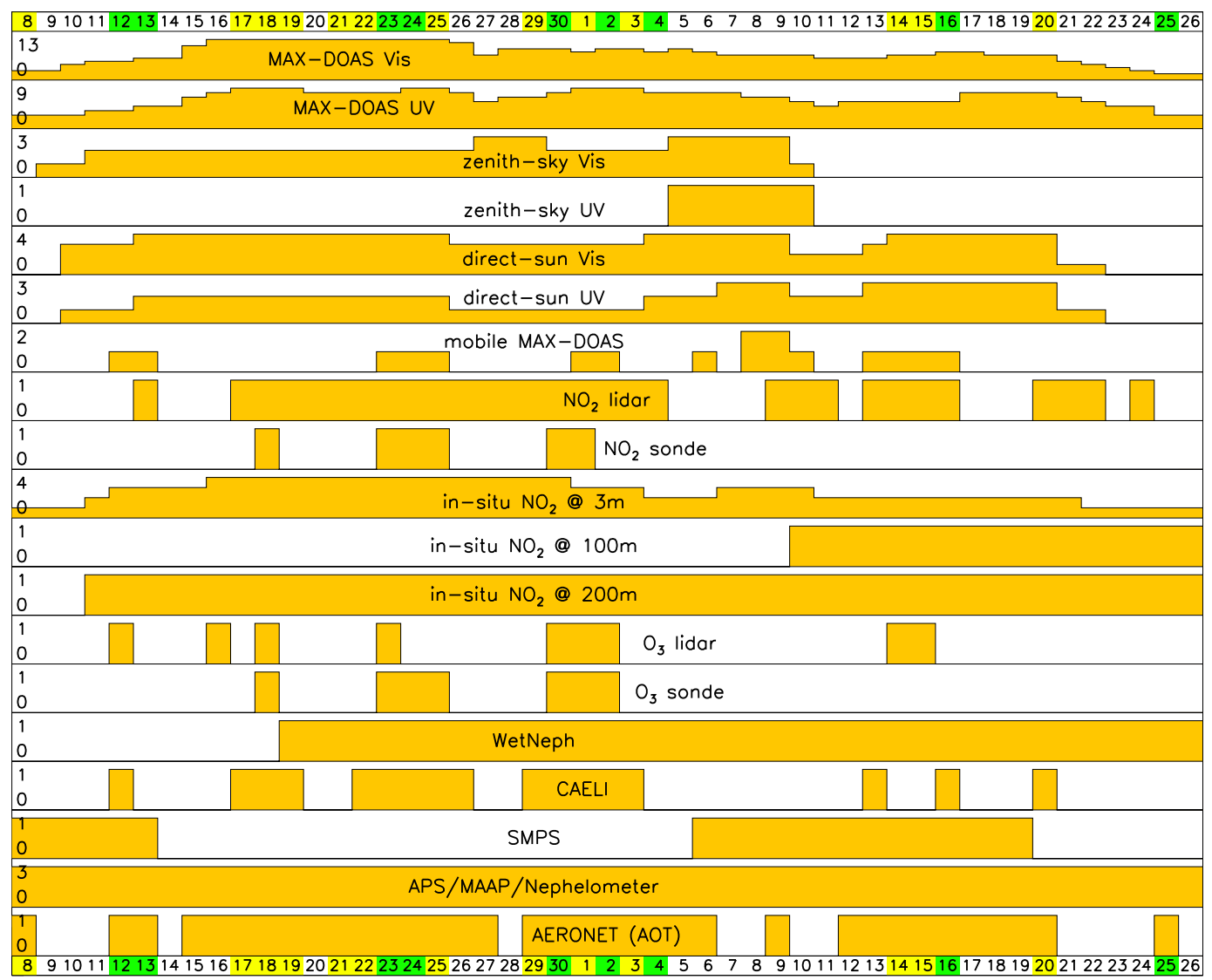

Fig. 9. Number of instruments which have collected data on each day during the CINDI campaign and for each of the instrument types. The day numbers in June and July are at the top and bottom of the figure. The yellow and green days are days of category A and B, respectively (see Sect. 3.1).

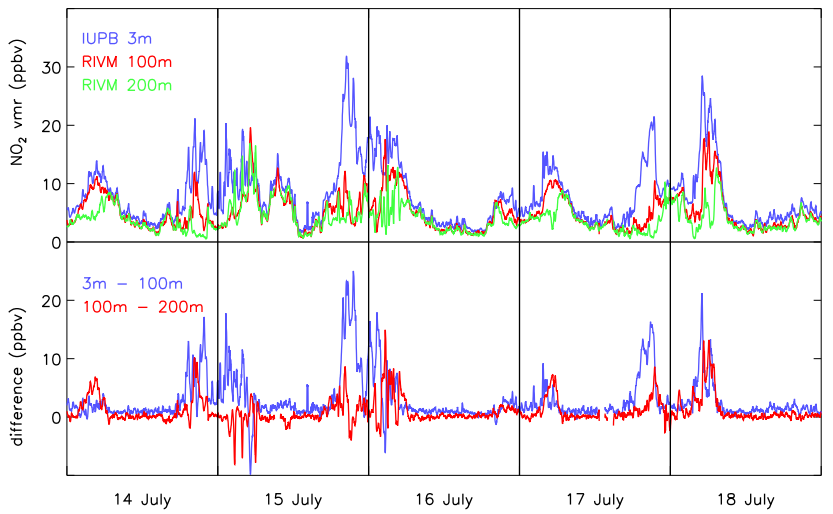

Fig. 10. In-situ measurements of $\mathrm{NO}_{2}$ taken at different altitude levels in the Cabauw tower. All measurements are performed with $\mathrm{NO}_{\mathrm{x}}$ analysers with photolytic converters. The upper graph shows the absolute values of the measurements at each level, the lower graph the differences. are sensitive to meteorological conditions, in particular the presence of high aerosol or cloud coverage, and therefore the retrieval study focused on selected sunny days.

Zenith only measurements are available between 9 June and 10 July. The University of Toronto DOAS instrument pointed towards zenith during the first part of the campaign. The CNRS SAOZ instruments were always pointing towards zenith. Combining the surface-based $\mathrm{SAOZ}$ instrument with the mini-SAOZ on top of the tower enabled to derive partial columns for the first $213 \mathrm{~m}$.

Mobile measurements were performed by two MAXDOAS instruments and one SAOZ instrument on 15 days between 12 June and 16 July, indicated in Fig. 9, on different tracks mostly within $30 \mathrm{~km}$ around Cabauw (see Fig. 5). Mobile measurements were also performed on longer tracks between Cabauw and Paris $(500 \mathrm{~km})$ on 6 and $10 \mathrm{July}$, between Cabauw and Mainz (400 km) on 13 June, and between Brussels and Cabauw $(150 \mathrm{~km})$ on 13 July. The $\mathrm{NO}_{2}$ lidar was operated on 28 days, indicated in Fig. 9. It measured $\mathrm{NO}_{2}$ profiles up to $2.5 \mathrm{~km}$ (sometimes up to $4 \mathrm{~km}$ ) the maximum altitude being determined from the loss of return signal at higher altitudes, depending on atmospheric conditions 
like the presence of aerosols, water vapour, or clouds. The measurements were performed all day. Only the presence of precipitation or dense fog prohibited measurements. A vertical $\mathrm{NO}_{2}$ profile is obtained by scanning a range of elevation angles, each elevation angle being sensitive to a different altitude. The lidar measured $\mathrm{NO}_{2}$ concentrations over a vertical range that depended on altitude, from $12 \mathrm{~m}$ range for a measurement at $12 \mathrm{~m}$ altitude to $1800 \mathrm{~m}$ for a measurement at $2200 \mathrm{~m}$ altitude. These concentrations are very accurate when compared to the in-situ monitors at 0,100 and $200 \mathrm{~m}$ altitude (Berkhout et al., 2012).

An experimental $\mathrm{NO}_{2}$ sonde was launched on 6 days, indicated in Fig. 9, at 10:30 UTC (Sluis et al., 2010). These sondes delivered high-resolution in-situ $\mathrm{NO}_{2}$ profiles up to $5 \mathrm{~km}$. On the same 6 days, at 13:30 UTC, ozone sondes were launched. Both ozone and $\mathrm{NO}_{2}$ sondes had a radiosonde attached to them, recording temperature, pressure, and relative humidity. In Bilthoven, $25 \mathrm{~km}$ north-east of Cabauw, an ozone lidar measured tropospheric ozone profiles on the same 6 days, every 20 to $30 \mathrm{~min}$.

Aerosol properties were measured by a suite of instruments. Measurements of aerosol optical depth (AERONET, only during daylight hours) and scattering and absorption coefficients were performed by in-situ systems during the entire duration of the campaign. The in-situ particle number size distribution for the smallest particles $(0.01$ to $0.5 \mu \mathrm{m})$, the SMPS, was not operational between 14 June and 5 July and after 19 July.

\section{Early results}

The extensive data set obtained during CINDI enables us to perform in-depth intercomparisons to assess the accuracy of the $\mathrm{NO}_{2}$ measuring instruments. These studies will point to the possible origins of differences in the derived geophysical parameters, and whether they are related to instrumental, algorithm, or interpretation differences.

\subsection{Accuracy of slant columns of $\mathrm{NO}_{2}, \mathrm{O}_{4}$, and $\mathrm{HCHO}$}

The first two weeks of the campaign, a semi-blind intercomparison was performed involving the 22 MAX-DOAS and zenith-sky instruments (Roscoe et al., 2010). These instruments pointed in the same direction and scanned almost the same air mass every 20-30 min. The wavelength range and other settings describing the DOAS analysis to obtain slant columns of $\mathrm{NO}_{2}$ and $\mathrm{O}_{4}$ were prescribed to minimise differences caused by these algorithms. Although no systematic investigation was performed to evaluate the impact of not following these recommendations, it is known from past experience (see e.g. Vandaele et al., 2005; Roscoe et al., 1999) that the use of different $\mathrm{NO}_{2}$ cross-sections can be a significant source of divergence. E.g. retrievals performed without consideration of the $\mathrm{NO}_{2}$ temperature dependence may
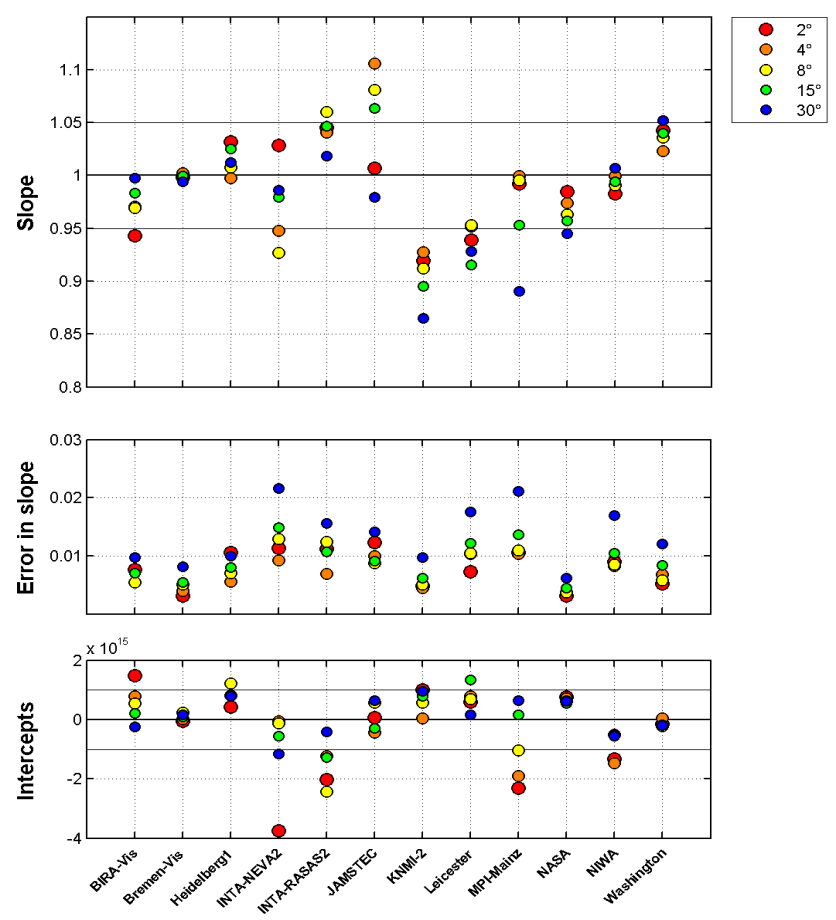

Fig. 11. Straight-line slopes and their standard errors and intercepts of $\mathrm{NO}_{2}$ slant columns for each instrument participating in the semi-blind intercomparison at visible wavelengths against those of a reference data set. Colours refer to elevation angles shown in the top right legend. Note that the MPIC Mainz instrument used a non-standard wavelength range for spectral analysis because of the limited range of the instrument (Fig. 6 from Roscoe et al., 2010).

introduce a bias as high as $20 \%$ on the slant columns. Comparatively the sensitivity to the wavelength range used for $\mathrm{NO}_{2}$ fitting is smaller, although bias can still be produced due to possible enhanced interference with water vapour absorption, the Ring effect or the wavelength dependency of the air mass factor. The 30-min averages of the slant column densities of $\mathrm{NO}_{2}$ and $\mathrm{O}_{4}$ matched within $5 \%$ for most of the participating instruments and all elevation angles (see Fig. 11). Restricting the comparison to zenith-sky data, it was concluded that all instruments meet the criteria for endorsement by NDACC (http://www.ndsc.ncep.noaa.gov/organize/ protocols). From the study, it became clear that a proper calibration of the elevation angles is crucial for the interpretation of the MAX-DOAS measurements. Also, the temporal variability of $\mathrm{NO}_{2}$ was quite large over typical measurement sampling time scales ( 6 to $30 \mathrm{~min}$, see Table A1). Therefore a significant part of the scatter in the comparisons was caused by time differences in the measurements. A better synchronisation of the measurements is necessary for future intercomparison exercises.

Slant columns of $\mathrm{HCHO}$ have been compared for a number of MAX-DOAS instruments. In order to reduce the retrieval impact, common retrieval settings (i.e. wavelength range, 

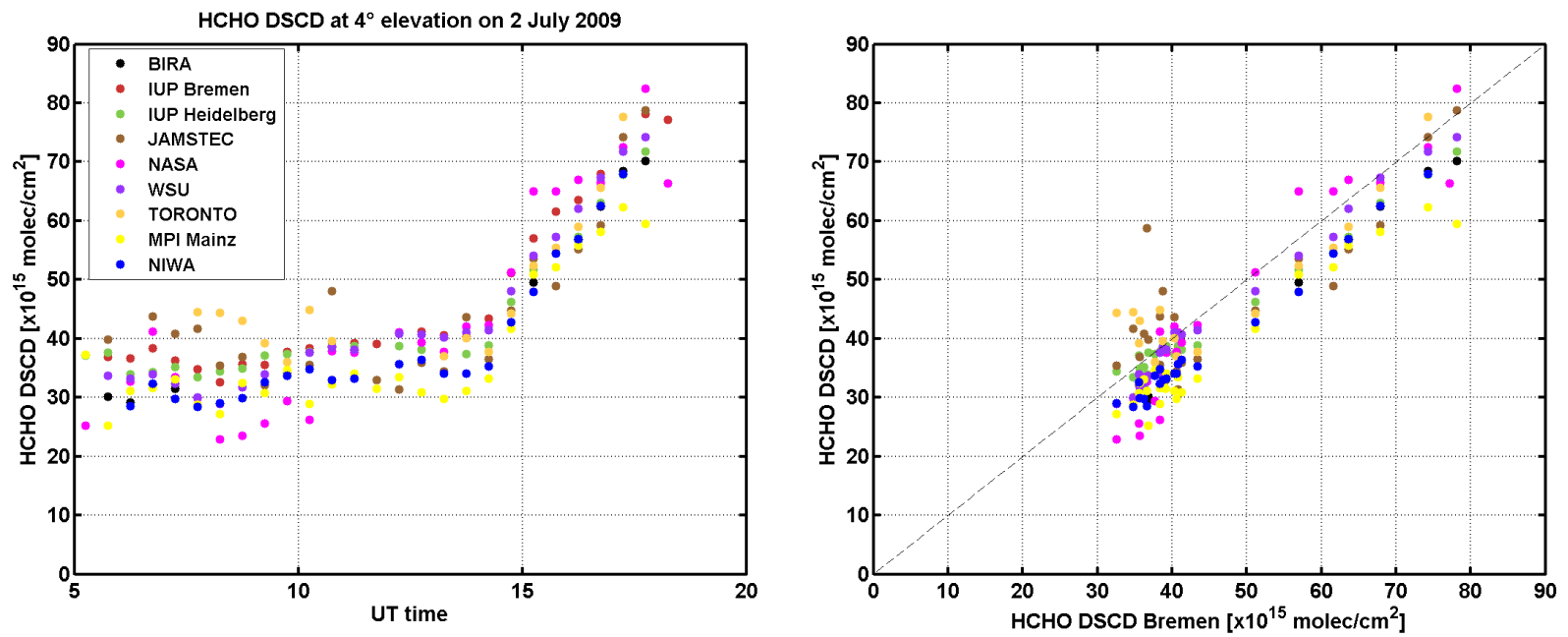

Fig. 12. Formaldehyde (HCHO) differential slant column density intercomparison for the data obtained on 2 July 2009 by all systems listed in the legend. The left panel shows the evolution over the day of the 30-min averaged slant columns retrieved from the $4^{\circ}$ elevation angle data, while the right panel shows their scatter plot with respect to the Bremen instrument (Pinardi et al., 2012).

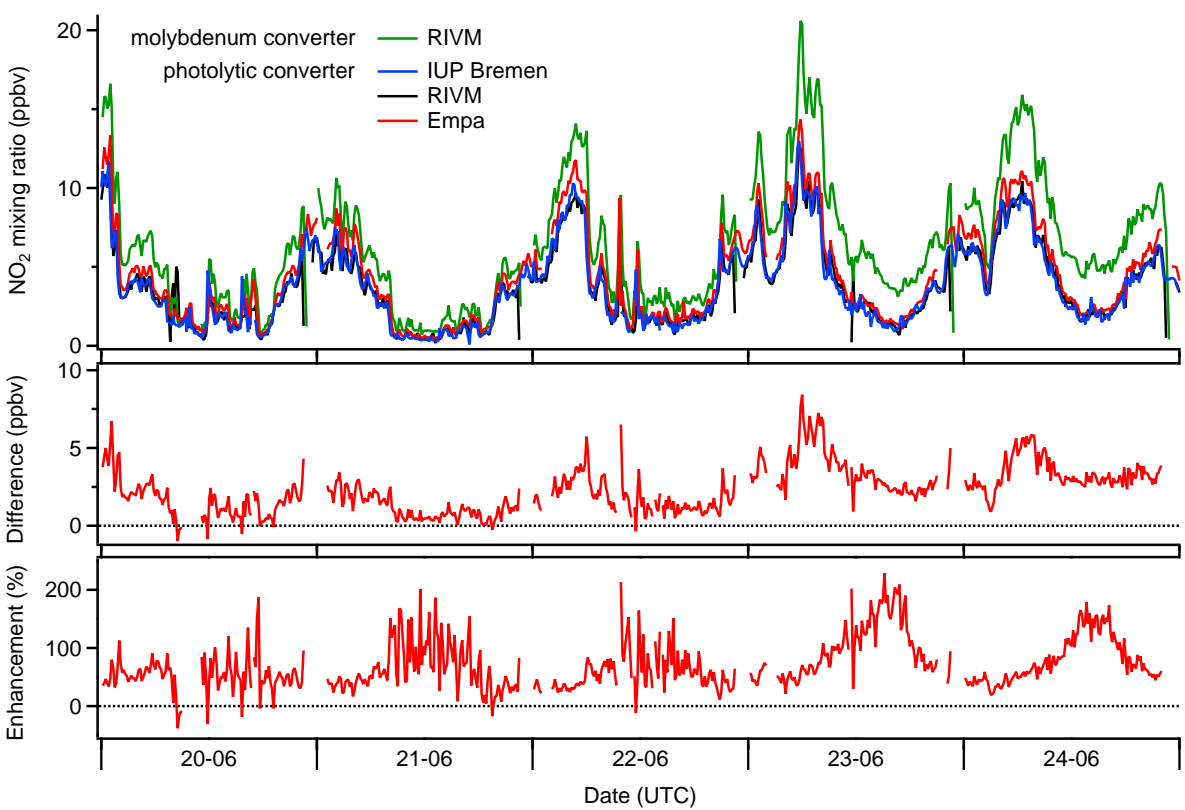

Fig. 13. Top panel: comparison of four in-situ atmospheric $\mathrm{NO}_{2}$ sampling instruments. The green line represents the instrument with a conventional hot-plate molybdenum converter, whereas the black, red and blue lines represent the instruments with a photolytic converter, from RIVM, Empa, and IUP Bremen, respectively. The middle and lower panels show the absolute and relative difference (enhancement) between the mixing ratio derived from the instrument with molybdenum converter and the average mixing ratio derived from the three other instruments.

cross-sections and DOAS settings) were used by the different groups and 30-min averages were taken to reduce differences in temporal sampling. An example of the comparison for 2 July 2009 and one elevation angle, including 8 different instruments, is presented in Fig. 12. Over the whole campaign, the HCHO slant columns retrieved by the different instruments from the off-axis elevations generally agreed within
$15 \%$ (Pinardi et al., 2012). This is a very encouraging result considering that this represents a first attempt to intercompare HCHO from MAX-DOAS instruments. 

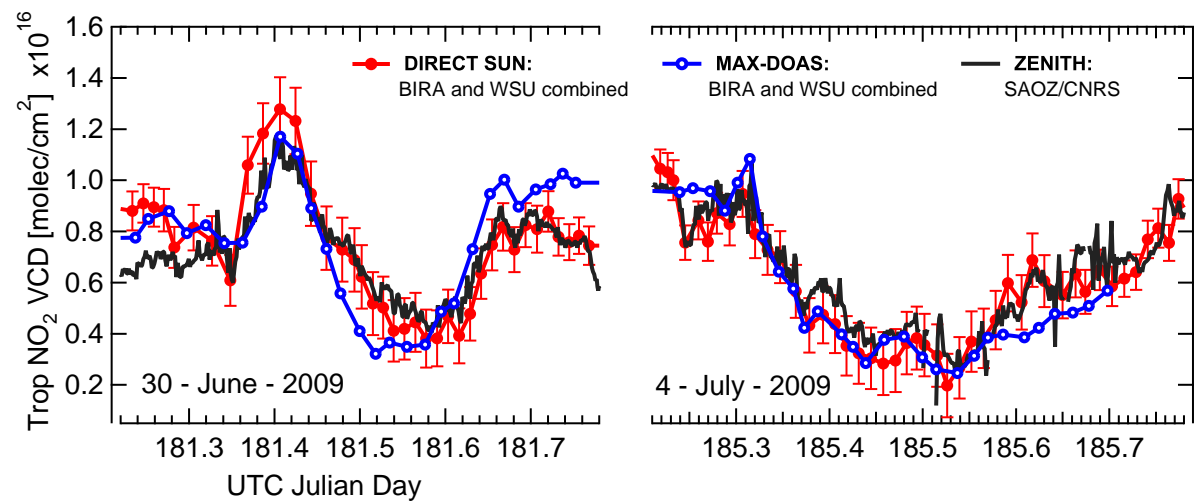

Fig. 14. Tropospheric $\mathrm{NO}_{2}$ columns derived from direct-sun (red) and MAX-DOAS (blue) measurements from the BIRA-IASB and WSU MAX-DOAS instruments, and from zenith-sky measurements (black) from the CNRS/SAOZ instrument, on 30 June and 4 July 2009. The measurements from BIRA-IASB and WSU were averaged for data points within 10 min of each other.

\subsection{Comparing $\mathrm{NO}_{2}$ concentration from in-situ monitors and lidar}

Five chemiluminescence in-situ monitors, one with a molybdenum converter from RIVM/LML, and four with a photolytic converter, from EMPA, RIVM (2 instruments), and IUP Bremen participated in the campaign. Figure 13 shows the measurements of four of these instruments over five days during the campaign. The instrument with molybdenum converter clearly has a positive bias with respect to the instruments with photolytic converters. This is most probably caused by the well-known interference with other species (e.g. with PAN and $\mathrm{HNO}_{3}$, see Winer et al., 1974). The bias, which is up to 5 ppbv, occurs both during day and night, but in relative terms is largest during the day, when solar UV induced atmospheric chemistry generates most of the interfering species.

On 15 and 16 July the RIVM $\mathrm{NO}_{2}$ lidar was placed at a distance of $2.1 \mathrm{~km}$ from the tower and pointed at the insitu instruments placed at three different altitudes. The horizontal distance of the $\mathrm{NO}_{2}$ lidar to the tower was chosen such that the air mass measured by the lidar contained the air mass sampled by the in-situ monitors. Berkhout et al. (2012) show that the lidar measurements follow the in-situ measurements within $5 \%$ and capture variations down to a $10 \mathrm{~min}$ time scale.

\subsection{Comparing tropospheric $\mathrm{NO}_{2}$ columns}

A first comparison was performed between the tropospheric vertical columns from MAX-DOAS, zenith-sky and directsun measurements (Spinei et al., 2012), see for example Fig. 14. The slant columns were converted to vertical columns, using air mass factors calculated with radiative transfer models (RTMs). The influence from stratospheric $\mathrm{NO}_{2}$ is negligible for MAX-DOAS measurements, but it has to be taken into account when tropospheric $\mathrm{NO}_{2}$ columns are derived from zenith-sky or direct-sun total column observations. In this case, the stratospheric $\mathrm{NO}_{2}$ column is determined from twilight observations according to methods in use within NDACC (e.g. Goutail et al., 1994; Hendrick et al., 2004; Chen et al., 2009). A linear regression between the BIRA-IASB and WSU data sets was performed showing agreement within $5 \%$ in all cases (direct-sun: slope 0.96, intercept $-2.36 \times 10^{14}$ molec $\mathrm{cm}^{-2}, R^{2} 0.98$; MAX-DOAS: slope 0.99 , intercept $-8.9 \times 10^{13}$ molec $\mathrm{cm}^{-2}, R^{2} 0.92$ ). Therefore, the measurements from BIRA-IASB and WSU were averaged for data points within $10 \mathrm{~min}$ of each other. SAOZ tropospheric columns were calculated using air mass factors based on MAX-DOAS derived profiles. The tropospheric columns of the three types of measurements agree on average within $30 \%$. Vlemmix et al. (2011) compared partial tropospheric vertical $\mathrm{NO}_{2}$ columns from the MAX-DOAS with those derived from the $\mathrm{NO}_{2}$ lidar (up to the maximum altitude of the lidar measurement). They found a correlation of 0.78 and an average difference of $0.1 \times 10^{15}$ molec cm $^{-2}$.

\subsection{Comparing vertical profiles of $\mathrm{NO}_{2}$}

Several different methods have been developed to retrieve vertical profiles from MAX-DOAS measurements (see, e.g. Wittrock et al., 2004; Heckel et al., 2005; Frieß et al., 2006; Irie et al., 2008, 2011; Clémer et al., 2010; Li et al., 2010; Wagner et al., 2011; Vlemmix et al., 2011). The strength and weaknesses of these methods are still not well understood and one of the objectives of CINDI was to further develop and improve ground-based profiling with MAX-DOAS. The number of degrees of freedom for MAX-DOAS profile retrievals is between 2 and 5, depending on clouds and aerosols and on the profile shape itself (see, e.g. Clémer et al., 2010; Vlemmix et al., 2011). The different retrieval methods were applied to well-prepared data sets of $\mathrm{NO}_{2}$ slant columns and compared to each other (Wittrock et al., 2012). The first data 


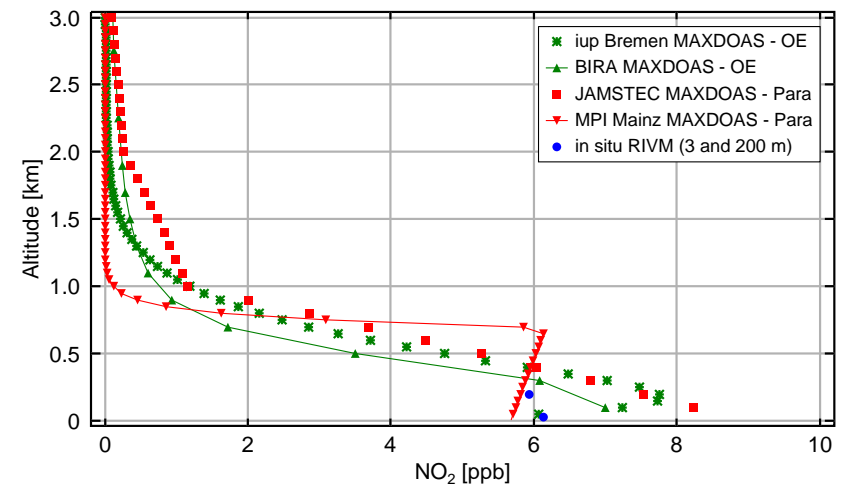

Fig. 15. $\mathrm{NO}_{2}$-profiles for 25 June 2009, 10:50 UTC for four different MAX-DOAS retrieval algorithms. In green are the profiles derived with the optimal estimation method, in red are the profiles derived with a simple parameterization method. In-situ data at 3 and $200 \mathrm{~m}$ levels are indicated in blue.

set consisted of modelled $\mathrm{NO}_{2}$ slant columns for a total of 16 different scenarios (eight $\mathrm{NO}_{2}$ profiles and two aerosol scenarios). Differences in results for this comparison can only be due to the retrieval techniques. The second comparison is on the retrieval of real data using fixed settings for all optimal-estimation-like retrieval techniques. For this exercise only data from the Bremen instrument have been analysed to avoid differences in $\mathrm{NO}_{2}$ results due to e.g. different timing of the instruments. For the comparison with complementary measurements from in-situ instruments, $\mathrm{NO}_{2}$-lidar and $\mathrm{NO}_{2}$ sondes, "best settings" for each MAX-DOAS were chosen by the different groups by using their own slant column results. Here, "best settings" means that all groups using optimal estimation (Rodgers, 2000) to retrieve the profile information usually apply different a priori information and also different numerical parameters to avoid physically meaningless results.

The model study showed that for the most important parameters - the tropospheric vertical column and the mixing ratio close to the surface - the different MAX-DOAS methods (including the non-optimal-estimation methods) are able to reproduce the true numbers within $20 \%$ even for higher aerosol $(\mathrm{AOD}=0.54)$ and more difficult scenarios like uplifted $\mathrm{NO}_{2}$ layers. As expected, the retrieval in the visible (around $450 \mathrm{~nm}$ ) is more stable and results are closer to reality than in the UV (around $350 \mathrm{~nm}$ ). When comparing the different retrieval algorithms using measured $\mathrm{NO}_{2}$ slant columns obtained by the Bremen instrument the agreement is very good (see e.g. Fig. 15). For surface concentrations and tropospheric columns the correlation is usually better than 0.9 , irrespective of atmospheric conditions, with slopes within $15 \%$ of unity. Comparison to complementary data from the $\mathrm{NO}_{2}$-lidar and in-situ instruments show reasonable agreement for surface layer mixing ratios on sunny days (correlation $R^{2}>0.7$ ) with slopes within $25 \%$ of unity.

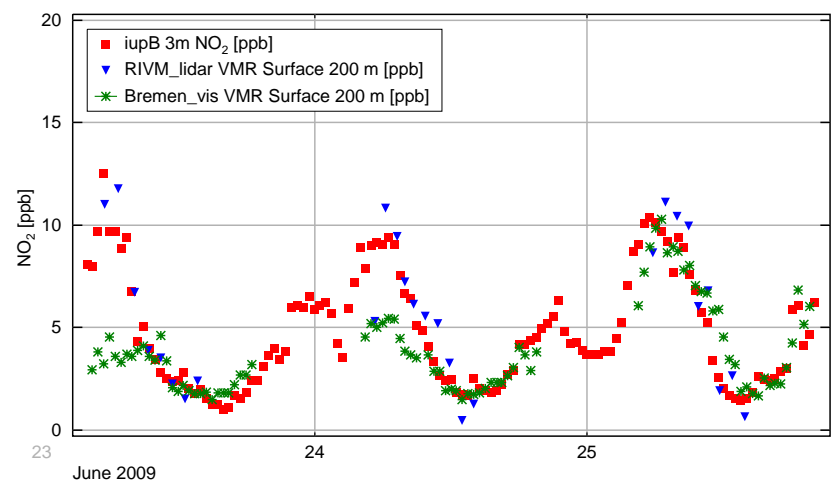

Fig. 16. $\mathrm{NO}_{2}$ surface concentrations for in-situ (IUP Bremen, red), lidar (RIVM, blue), and MAX-DOAS (IUP Bremen, green).

For atmospheric conditions with a very low boundary layer height of less than $300 \mathrm{~m}$ the MAX-DOAS profile retrievals significantly underestimate the "real" $\mathrm{NO}_{2}$ concentration by up to $50 \%$ as shown in Fig. 16 for 23 and 24 June.

\subsection{Comparing vertical profiles and optical depth of aerosol}

Aerosol extinction vertical profiles were retrieved from MAX-DOAS measurements by five groups (BIRA-IASB, IUP Heidelberg, JAMSTEC, KNMI and MPIC Mainz). While some of the retrieval algorithms retrieve full vertical profiles using optimal estimation, others use more simple least squares algorithms to retrieve one or two parameters (e.g. aerosol optical thickness and layer height). Despite the large differences in the retrieval approaches, a comparison with ceilometer measurements demonstrates that the general structure of the boundary layer from MAX-DOAS observations of $\mathrm{O}_{4}$ compares favourably (see Fig. 17). Reasonable agreement is achieved between the resulting aerosol optical thickness from MAX-DOAS and AERONET measurements, with regression coefficients better than 0.8 and slopes ranging between 0.7 and 1.2. MAX-DOAS retrievals are less sensitive to aerosol layers at higher altitudes, as was seen by a comparison with aerosol extinction profiles from Caeli. A publication of the results from the aerosol intercomparison is in preparation (Frieß et al., 2012).

\subsection{Comparing surface aerosol extinction}

Zieger et al. (2011) compared the lowest levels of the surface aerosol extinction profiles retrieved by four MAXDOAS instruments, using different algorithms, with in-situ surface values of the aerosol extinction. These in-situ values were determined from the combination of measurements of the scattering coefficients at different relative humidities and the dry absorption coefficient. Zieger et al. (2011) found good correlation between the MAX-DOAS instruments and the Caeli lidar with in-situ extinction values, but 


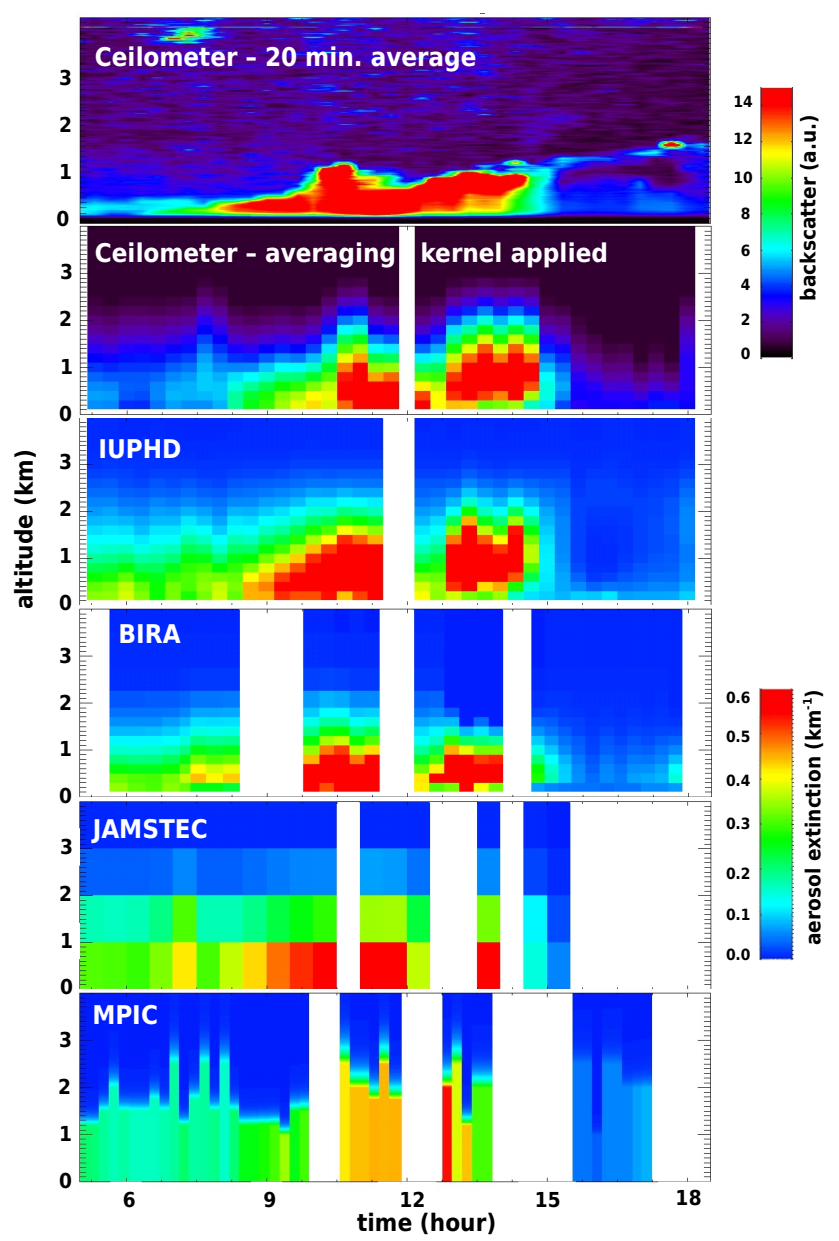

Fig. 17. Aerosol profile intercomparison for 3 July (Frieß et al., 2012). The top plot shows the backscatter profiles from the Ceilometer at Cabauw. The second plot shows the same data with MAX-DOAS averaging kernels applied. The plots below that show the aerosol extinction profiles of the MAX-DOAS instruments from BIRA-IASB, IUP Heidelberg, JAMSTEC and MPIC Mainz (topdown), respectively.

the MAX-DOAS data are generally significantly larger than the corresponding in-situ values by a factor $\sim 1.5$ to 3.4 . The Caeli lidar values (extrapolated to the ground using the measured backscatter signal) were a factor of 1.12 to 1.76 larger than the in-situ values. Several hypotheses were brought forward, for example the limited vertical resolution of the MAX-DOAS retrieval (especially during lofted layers) and possible particle losses in the in-situ inlet system. Zieger et al. (2011) found that the agreement is better for low AOD and low PBL cases (see Fig. 18). The retrieval for some of the instruments also improved when ambient in-situ measurements of the asymmetry factor and the single scattering albedo were used as input.

\section{Outlook and potential of the CINDI data set}

Section 4 highlights the most important results from the CINDI campaign until now. More studies with the comprehensive CINDI data set are anticipated. A main objective of the CINDI campaign is to determine the potential of the observations by the atmospheric $\mathrm{NO}_{2}$ measuring ground-based instruments for validation of tropospheric $\mathrm{NO}_{2}$ columns derived from satellite observations by, e.g. OMI aboard EOSAura, SCIAMACHY aboard Envisat, and GOME-2 aboard METOP. Here the most important aspect is the accuracy of the determined tropospheric columns and vertical profiles, which is obtained by quantifying the performance of the measurements and retrieval methods under different atmospheric conditions. The CINDI data set provides an excellent opportunity to study this. The experiment with different viewing directions, as described in Sect. 2.5.2, will be used to study the overall consistency of air mass factor calculations, especially related to viewing geometry, aerosol and cloud properties and horizontal and vertical distributions of trace gases. By combining measurements taken under different viewing directions, elevation angles, and different relative azimuth angles, inconsistencies in the assumptions on aerosol and boundary layer height can be further investigated. Another valuable source of information on the consistency of air mass factors can be derived from the comparison between the direct-sun and the scattered light measurements.

An important aspect to be taken into consideration when comparing ground-based and satellite-borne remote-sensing observations is their difference in sensitivity to trace gas abundances as a function of the altitude at which it resides. This can be studied by theoretical simulations using a radiative transfer model, and the CINDI data can be used to verify these simulations by combining the MAX-DOAS and zenith-sky measurements at different viewing geometries and under different atmospheric conditions with the in-situ measurements at different altitudes.

Another important aspect is the difference in sampling of the air mass in the respective field of view. In the horizontal spatial domain the satellite observes ground-pixel footprints at the 30 to $100 \mathrm{~km}$ scale, while the ground-based MAXDOAS horizontal field of view is at most a few $\mathrm{km}$ in the viewing direction and a few $100 \mathrm{~m}$ in the across viewing direction. The horizontal variability in $\mathrm{NO}_{2}$ along a satellite ground pixel can be quite large, as can be seen from the mobile measurement track in Fig. 5, which spans an area of approximately $30 \times 40 \mathrm{~km}^{2}$ and shows a range in $\mathrm{NO}_{2}$ values of a factor of 6 ; this variability is averaged over the satellite ground pixel footprint.

The mobile measurements will be combined with the measurements from Cabauw in several viewing directions and with air-quality models to map typical horizontal distributions of $\mathrm{NO}_{2}$ and quantify the effect of such distributions in the interpretation of satellite measurements. 

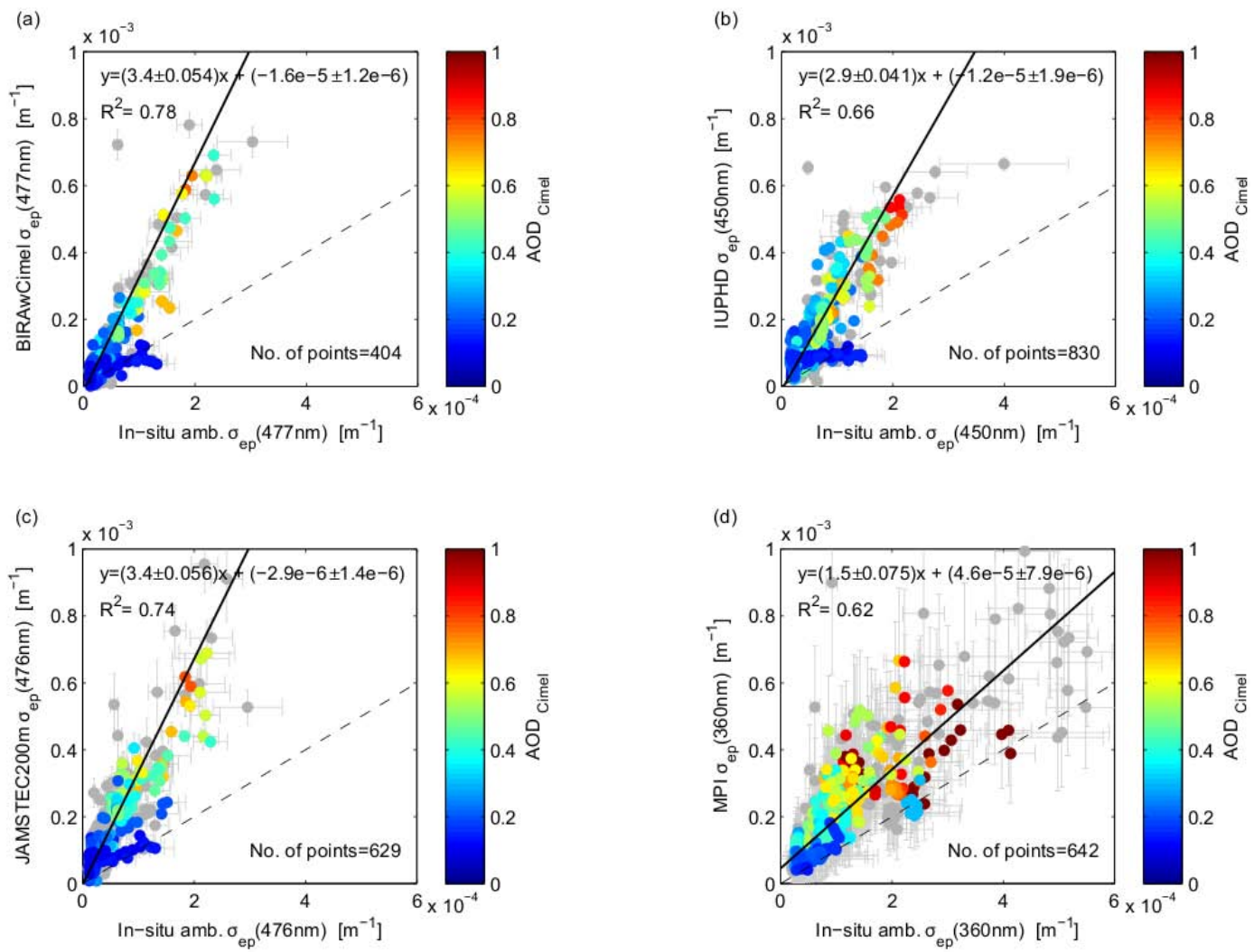

Fig. 18. Ambient aerosol extinction coefficient retrieved from MAX-DOAS observations versus in-situ measurements brought to ambient conditions. The colour denotes the AOD measured by the Cimel sun photometer (AOD interpolated in accordance with the appropriate wavelength; grey points are times with no sun photometer measurements). The solid black line represents a bivariate linear regression including weights (with calculated uncertainty of slope and intercept). The dashed line is the 1:1-line (Fig. 8 from Zieger et al., 2011).

During thirty-one days the CINDI campaign experienced sunny conditions during one or more daily satellite overpasses, as detailed in Appendix C. These satellite overpasses can be used to study the consistency of the satellite retrievals and the assumptions about aerosol and $\mathrm{NO}_{2}$ profiles with the results derived from CINDI data.

This campaign should result in recommendations for optimal instrumental and retrieval settings, optimal observation strategies, and optimal intercomparison methods for the ground-based systems involved.

\section{Conclusions}

The CINDI campaign has been very successful in achieving its observational and scientific objectives. A large data set of continuous ground-based in-situ and remote sensing observations of nitrogen dioxide, aerosols and other air pollution constituents has been collected under various meteorological conditions and under various air pollution loadings. The campaign included many cloud-free periods: nine days were labelled as "category A" days with at least 10 sunny hours, and 13 days as "category B" days with at least 4 sunny hours. The day-to-day variability of $\mathrm{NO}_{2}$ for sunny days was mostly driven by wind direction, with cleaner air coming from northerly directions. The CINDI campaign experienced periods of enhanced $\mathrm{SO}_{2}$ with winds coming from the North Sea, possibly originating from ship emissions, and periods of enhanced $\mathrm{HCHO}$ with warm winds coming over land, suggesting an origin of biogenic emissions (Irie et al., 2011). The skies above Cabauw were observed in multiple azimuthal and elevation directions by the MAX-DOAS and direct-sun instruments from morning to evening twilight. First detailed comparisons performed with the CINDI data show that

- MAX-DOAS slant column measurements of $\mathrm{NO}_{2}$ and $\mathrm{O}_{4}$ agree within 5-10\% (Roscoe et al., 2010);

- MAX-DOAS slant column measurements for HCHO agree within $\sim 15 \%$ (Pinardi et al., 2012);

- the bias that in-situ $\mathrm{NO}_{2}$ measurements derived with a molybdenum converter suffer from interfering species can be as large as 5 ppbv during day time (Sect. 4.2);

- the $\mathrm{NO}_{2}$ lidar measurements agree with in-situ measurements within $5 \%$ (Berkhout et al., 2012); 
- tropospheric columns and surface values of $\mathrm{NO}_{2}$ from MAX-DOAS $\mathrm{NO}_{2}$ profile retrievals agree within $15 \%$ between different instruments, and within $25 \%$ with the $\mathrm{NO}_{2}$ lidar data and in-situ $\mathrm{NO}_{2}$ data obtained at different altitudes, except for the situation of very shallow boundary layers, where the MAX-DOAS algorithms underestimate the $\mathrm{NO}_{2}$ values by up to $50 \%$ (Wittrock et al., 2012);

- MAX-DOAS aerosol optical depth is in reasonable agreement with the AERONET measurements, with regression coefficients better than 0.8 and slopes ranging between 0.7 and 1.2 (Frieß et al., 2012, ; Sect. 4.5);

- MAX-DOAS aerosol extinction values are generally well correlated with, but a factor $\sim 1.5$ to 3.4 larger than, the corresponding in-situ values at the surface (Zieger et al., 2011).

Other studies that are currently being performed include the comparisons of tropospheric $\mathrm{NO}_{2}$ columns, aerosol profiles, ozone profiles, and $\mathrm{HCHO}$ columns, the spatial variability of $\mathrm{NO}_{2}$, and the application to satellite data validation.

It is expected that the studies performed during the CINDI campaign will result in increased knowledge about the performance of ground-based remote sensing instruments regarding the accuracy with which $\mathrm{NO}_{2}$ and aerosol information in terms of vertical profiles and tropospheric/total columns can be derived. The intercomparisons will result in harmonization of retrieval settings and observation methods, and in recommendations for building the networks of ground-based systems urgently needed for satellite data validation.

\section{Appendix A}

\section{Descriptions of participating instruments}

This Appendix gives detailed descriptions of most of the participating instruments. Table 1 in Sect. 2.3 lists some more details of the spectrometers, in particular on field of view, wavelength range and resolution. Table A1 lists the elevation angles, and integration times used during CINDI for each of the systems. Table 2 in Sect. 2.3 lists the location and measurement parameters of the other participating instruments.

\section{A1 MAX-DOAS instruments}

\section{BIRA-IASB MAX-DOAS}

The BIRA-IASB MAX-DOAS instrument is a dualchannel system, with a UV and a VIS spectrometer, an ORIEL MS260i with a grating consisting of 1200 grooves $\mathrm{mm}^{-1}$ and an ORIEL MS127 with a grating of 600 grooves $\mathrm{mm}^{-1}$, respectively. For both the UV and the VIS spectrometer, the instrumental response function is close to a Gaussian. The output of the spectrometers is connected to two low-noise thermo-electrically cooled CCD detector systems with $2048 \times 512$ and $1340 \times 100$ pixels for the UV and VIS, respectively. The optical head, mounted on a sun-tracker, can collect direct-sun and scattered light at various elevation $\left(0\right.$ to $\left.90^{\circ}\right)$ and azimuth angles $\left(0\right.$ to $\left.360^{\circ}\right)$. The optical head also includes a 6-position filter wheel equipped with transmission diffuser plates and neutral density filters. A full description of the instrument can be found in the publication by Clémer et al. (2010).

\section{BIRA-IASB mobile DOAS}

The BIRA-IASB mobile-DOAS instrument (Merlaud et al., 2012) is based on two similar compact Avantes spectrometers installed on a car. The entry slit is $50 \mu \mathrm{m}$, the focal length $75 \mathrm{~mm}$ and the grating is a $6001 \mathrm{~mm}^{-1}$, blazed at $300 \mathrm{~nm}$. The CCD detector is a Sony 2048 linear array with a DeepUV coating for signal enhancement below $350 \mathrm{~nm}, 40$ photons per count sensitivity at $600 \mathrm{~nm}$ and a signal-to-noise ratio of 200. An optical head, mounted on the car window, holds the two telescopes with fused silica collimating lenses. One telescope points zenith while the other is directed $30^{\circ}$ above the horizon. Two $400 \mu \mathrm{m}$ chrome plated brass optical fibres connect the telescopes to the spectrometer. A GPS antenna is used for geolocation referencing of the measurements, the whole set-up is powered by the car battery $12 \mathrm{~V}$ through an inverter. While measuring, the instrument is recording spectra continuously and simultaneously from the two directions. The instrument was operated on the local roads around Cabauw and on the highways between Utrecht and Rotterdam.

\section{BIRA-IASB, KNMI, MPIC Mainz and GIST mini MAX-DOAS instruments}

Six mini-MAX-DOAS instruments were present during the campaign. The mini-MAX-DOAS is a commercial system from Hoffmann Messtechnik GmbH, consisting of an Ocean Optics spectrograph, diffraction grating, and a CCD detector. The whole instrument is contained in a compact metal box $\left(13 \times 19 \times 14 \mathrm{~cm}^{3}\right)$ mounted on a stepper motor, allowing the change in viewing elevation angle. It has an active Peltier cooler. The six instruments differ in their spectrographs, so that the wavelength ranges, resolution and field of view are slightly different, see Table 1 in Sect. 2.3.

\section{INTA MAX-DOAS NEVA-II}

NEVA-II is a robust house-made instrument developed for continuous operation in continental Antarctica. It is based on a HAMAMATSU S7031-1008 (256 rows $\times 1024$ pixels) CCD sensor. The read-out electronics is designed and developed at INTA, achieving a typical CCD node sensitivity of $2.2 \mu \mathrm{V} / \mathrm{e}^{-}$and typical read-out noise of $8 \mathrm{e}^{-}$operating at $-40^{\circ} \mathrm{C}$. The spectrograph is a TRIAX 180 (Czerny-Turner) 
Table A1. Elevation angles, integration times and full scan durations of the MAX-DOAS systems during CINDI.

\begin{tabular}{|c|c|c|c|}
\hline Institute/instrument & Elevation angles & $\mathrm{IT}^{1}$ & full scan \\
\hline BIRA-IASB D. Channel & $1^{\circ}, 2^{\circ}, 3^{\circ}, 4^{\circ}, 5^{\circ}, 8^{\circ}, 10^{\circ}, 15^{\circ}, 30^{\circ}, 90^{\circ}$ & 0.1 to $60 \mathrm{~s}$ & $15 \mathrm{~min}$ \\
\hline BIRA-IASB MMD & $-0.5^{\circ}, 0^{\circ}, 2^{\circ}, 4^{\circ}, 6^{\circ}, 8^{\circ}, 10^{\circ}, 15^{\circ}, 30^{\circ}, 85^{\circ}$ & $1 \mathrm{~min}$ & $15 \mathrm{~min}$ \\
\hline BIRA-IASB mobile & $30^{\circ}, 90^{\circ}$ & $1 \mathrm{~min}$ & $2 \mathrm{~min}$ \\
\hline IUP-Bremen D. Channel & 20 angels & $40 \mathrm{~s}$ & $15 \mathrm{~min}$ \\
\hline GIST MMD UV & $0^{\circ}, 1^{\circ}, 2^{\circ}, 3^{\circ}, 4^{\circ}, 5^{\circ}, 8^{\circ}, 10^{\circ}, 15^{\circ}, 30^{\circ}, 90^{\circ}$ & $2 \min$ & $20 \mathrm{~min}$ \\
\hline IUP-Heidelberg DOAS 1 & $2^{\circ}, 4^{\circ}, 8^{\circ}, 15^{\circ}, 30^{\circ}, 90^{\circ}$ & $1 \mathrm{~min}$ & $6 \min$ \\
\hline IUP-Heidelberg DOAS 2 & $2^{\circ}, 4^{\circ}, 8^{\circ}, 15^{\circ}, 30^{\circ}, 90^{\circ}$ & $1 \mathrm{~min}$ & $6 \mathrm{~min}$ \\
\hline INTA NEVA-II & $5^{\circ}, 9^{\circ}, 16^{\circ}, 31^{\circ}, 90^{\circ}$ & $0.1 \mathrm{~s}$ & $20 \mathrm{~min}$ \\
\hline INTA RASAS-II & $3^{\circ}, 4^{\circ}, 5^{\circ}, 8^{\circ}, 10^{\circ}, 15^{\circ}, 30^{\circ}, 90^{\circ}$ & $10 \mathrm{~s}$ & $15 \mathrm{~min}$ \\
\hline JAMSTEC & $2^{\circ 2}, 4^{\circ}, 8^{\circ}, 15^{\circ}, 30^{\circ}, 90^{\circ}$ & $40 \mathrm{~ms} / 5 \mathrm{~min}$ & $30 \mathrm{~min}$ \\
\hline KNMI MMD UV & $0^{\circ}, 2^{\circ}, 4^{\circ}, 8^{\circ}, 15^{\circ}, 30^{\circ}, 85^{\circ}$ & $2 \min$ & $15 \mathrm{~min}$ \\
\hline KNMI MMD VIS & $0^{\circ}, 2^{\circ}, 4^{\circ}, 8^{\circ}, 15^{\circ}, 30^{\circ}, 90^{\circ}$ & $1 \mathrm{~min}$ & $15 \mathrm{~min}$ \\
\hline Univs Leicester\&Leeds & $1^{\circ}, 2^{\circ}, 3^{\circ}, 4^{\circ}, 5^{\circ}, 6^{\circ}, 8^{\circ}, 10^{\circ}, 15^{\circ}, 30^{\circ}, 90^{\circ}$ & 1 to $2 \min ^{3}$ & $20 \mathrm{~min}$ \\
\hline MPIC-Mainz MMD & $-5^{\circ},-0.5^{\circ}, 0^{\circ}, 2^{\circ}, 4^{\circ}, 6^{\circ}, 8^{\circ}, 10^{\circ}, 15^{\circ}, 30^{\circ}, 85^{\circ}$ & $1 \min$ & $15 \mathrm{~min}$ \\
\hline MPIC-Mainz mobile & $22^{\circ}, 45^{\circ}, 90^{\circ}$ & $1 \mathrm{~min}$ & $3 \min$ \\
\hline NASA PANDORA $(2,3)$ & $0^{\circ}, 15^{\circ}, 30^{\circ}, 45^{\circ}, 60^{\circ}, 75^{\circ}, 80^{\circ}, 82^{\circ}, 85^{\circ}, 86^{\circ}, 87^{\circ}, 88^{\circ}, 89^{\circ}$ & $300 \mathrm{~ms} / 20 \mathrm{~s}$ & $5 \mathrm{~min}$ \\
\hline NIWA & $1^{\circ}, 2^{\circ}, 4^{\circ}, 8^{\circ}, 10^{\circ}, 15^{\circ}, 30^{\circ}, 90^{\circ}$ & 0.016 to $20 \mathrm{~s} / 120 \mathrm{~s}$ & $17 \mathrm{~min}$ \\
\hline Univ. Toronto & $2^{\circ}, 4^{\circ}, 8^{\circ}, 15^{\circ}, 30^{\circ}, 90^{\circ}$ & $15 \mathrm{~ms}$ to $30 \mathrm{~s} / 5 \mathrm{~min}$ & $30 \mathrm{~min}$ \\
\hline WSU MF-DOAS & $3^{\circ}, 4^{\circ}, 5^{\circ}, 8^{\circ}, 10^{\circ}, 15^{\circ}, 30^{\circ}, 90^{\circ}$ & $0.63 \mathrm{~s}, 1.2 \mathrm{~s}^{4}$ & $10 \mathrm{~min}$ \\
\hline
\end{tabular}

Notes: ${ }^{1}$ The MAX-DOAS systems add up a number of spectra at smaller integration times to avoid saturation. The integration time reported here is the total integration time for one elevation angle. Where two times (or time ranges) are given, the smaller one is the typical integration time (or time range) of a single spectrum; ${ }^{2} 3^{\circ}$ between 8 and 21 June; ${ }^{3} 2$ min for each angle submitted to the comparison exercise, 1 min for all other angles; ${ }^{4}$ single scan duration for vis and UV respectively.

holding a 1200 grooves $\mathrm{mm}^{-1}$ holographic grating. The system is located in a waterproof housing stabilized at $23^{\circ} \mathrm{C}$. Dry Nitrogen is supplied to keep the humidity inside below $5 \%$. Depolarized light reaches the spectrograph through a $10 \mathrm{~m}$ fused silica fibre bundle. The optical telescope is designed to stand $1^{\circ}$ field of view. Tilt telescope movement is controlled by thermally-controlled stepping motors. Measurements were performed in a continuous mode whenever SZA $<98^{\circ}$. NEVA-II was operating in zenith mode around twilight (SZA $>80^{\circ}$ at dawn and $\mathrm{SZA}>70^{\circ}$ at dusk) and in off-axis mode the rest of the day.

\section{INTA MAX-DOAS RASAS-II}

RASAS-II is based on an Andor IDUS UV CCD camera (model DU420A-BU) and a Shamrock SR163i (Czerny-Turner) spectrograph holding a grating of 600 grooves $\mathrm{mm}^{-1}$. The $\mathrm{CCD}$ was operating at $-40^{\circ} \mathrm{C}$ to minimize dark current of the detector. The housing and optics are similar to those of the previously described NEVA-II. The fibre telescope pan and tilt positioner is a Direct Perception PTV-D47. During the first period of CINDI the instrument operated in the visible range for $\mathrm{NO}_{2}$ measurements. From 6 July onwards the spectral range was shifted to the UV for $\mathrm{HCHO}$ and $\mathrm{BrO}$ measurements.

\section{IUP-Bremen MAX-DOAS}

The instrument from IUP Bremen (Wittrock et al., 2004) consists of two grating spectrometers - one for the UV and one for the VIS - and a separate telescope unit connected to the two channels via a Y-shape quartz fibre bundle. The spectrometers are temperature stabilized to avoid wavelength drifts. The $20 \mathrm{~m}$ quartz fibre bundle with 76 cylindrical single fibres, each of which has a diameter of $150 \mu \mathrm{m}$, efficiently depolarizes the incoming light and also provides flexibility for the instrument set-up. The telescope housing is based on a commercial watertight box, where optical components like a lens restricting the FOV to $1.2^{\circ}$, a $\mathrm{HgCd}$ lamp for spectral calibrations and a commercial video camera are fitted in. The box is mounted on a pan-tilt-head which is able to turn in almost any direction with high speed. In contrast to most of the other instruments, scans in different azimuth angles were carried out during the campaign. The power consumption for the whole set-up is about 1000 VA peak, space required inside $1 \mathrm{~m}^{2}$.

\section{JAMSTEC MAX-DOAS}

The JAMSTEC MAX-DOAS instrument consists of a telescope unit placed outdoors and a spectrometer unit indoors. These were connected by a multimode step-index fibre (NA $=0.22$, pure silica). A miniaturized UV/visible spectrometer (Ocean Optics USB4000) equipped with a 
3648-element 1D CCD was used to record the spectra. Its temperature was kept constant at $40.0 \pm 0.1^{\circ} \mathrm{C}$. Integration time was kept constant throughout the day at around $100 \mathrm{~ms}$. Spectra recorded at a fixed elevation angle for a $5 \mathrm{~min}$ interval were averaged and analysed. The telescope unit was placed on the roof of one of the temporary cabins. A single planoconvex lens (focal length $=40 \mathrm{~mm}$ and diameter $=25 \mathrm{~mm}$ ) was used to focus the received sunlight onto the fibre. Window and lens are both made of quartz without optical coatings. A movable mirror (UV reflecting) in the telescope unit was controlled by a PC to record spectra sequentially at six different elevation angles. Power consumption was roughly estimated to be less than 200 VA for the whole system, including a PC.

\section{NASA Pandora 2, 3, and 9}

Pandora's head sensor consists of a quartz entrance window, one or two 9-position filter-wheels (opaque, UV-optical band-pass filters, polarizers, neutral density filters), and a quartz lens focusing on a single-strand fibre. The head sensor is mounted on a tracker capable to point at any position in the sky up to a zenith angle of $110^{\circ}$. The $10 \mathrm{~m}$ long fibre with NA of 0.12 acts as a depolarizer and transmits the light to the Avantes mini-spectrometer. Pandora has non-cooled Hamamatsu detectors (CCD or CMOS). The spectrometer is temperature stabilized to $10 \pm 3{ }^{\circ} \mathrm{C}$. The complete system weighs about $12 \mathrm{~kg}$. The maximum power consumption is 200 W. Pandora 9 is a sun-only instrument. It took direct-sun data from sunrise to sunset using different optical band-pass filters in the filter-wheel. A direct-sun measurement consists of multiple spectra at typically $10 \mathrm{~ms}$ integration time for a total of $40 \mathrm{~s}$. Pandora 2 and 3 took 1 direct-sun measurement per 5 elevation scans.

\section{NIWA MAX-DOAS}

The NIWA MAX-DOAS instrument consists of an ISA HR320 (a $0.32 \mathrm{~m}$ Czerny-Turner monochromator) fitted with additional internal baffles. A Hamamatsu 7420 detector with S7032-1007 cooled $-20^{\circ} \mathrm{C}$ back-thinned CCD with $1044 \times 128$ pixels is used with FFT-CCD in line binning mode. The dark signal is $1 e^{-} /$pixel s$^{-1}$ and the readout noise $8 e^{-} \mathrm{s}^{-1}$. The telescope optics consists of a fibre optic with multiple $100 \mu \mathrm{m}$ diameter fibres, which removes polarization, and an F/4 lens. The fibre optic connects vertically to an elevation-azimuth tracker. The power usage of the NIWA MAX-DOAS was $120 \mathrm{~W}$. The instrument was installed in a metal box of somewhat less than $1 \mathrm{~m}^{3}$. The instrument box had a thermoelectric cooler and was additionally cooled with room air from the cabin during the latter part of the campaign when ambient temperatures were high.

\section{Universities of Leicester and Leeds MAX-DOAS}

The MAX-DOAS operated jointly by the Universities of Leicester and Leeds during the CINDI campaign briefly comprised of a $25 \mathrm{~mm}$ diameter telescope, built at the University of Leeds, with a $7.5 \mathrm{~cm}$ focal length mounted on a stepper motor for elevation angle control. The telescope and stepper motor were housed within a heated protective case with the telescope connected via a $10 \mathrm{~m}$ fibre optic bundle to a temperature stabilized PI Acton Insight Spectrometer inside the building. The spectrometer, with a grating of 1200 lines per $\mathrm{mm}$, was housed in a case stabilized to $\pm 0.1 \mathrm{~K}$. The CCD detector used (PI Acton model: Pixis 1024) is back illuminated and contains 1024 rows and 1024 columns with a pixel size of $13 \times 13 \mu \mathrm{m}^{2}$ giving a total imaging area of $13.3 \times 13.3 \mathrm{~mm}^{2}$. The camera is kept in a permanent vacuum and maintained at a constant temperature of $-42{ }^{\circ} \mathrm{C}$ using a thermo-electric Peltier cooler. Spectra were collected from averages over the central 500 rows of the CCD.

\section{University of Toronto Ground-Based Spectrometer (UT-GBS)}

The University of Toronto Ground-Based Spectrometer (UTGBS) collects sunlight with a $40 \mathrm{~mm}$-diameter fused silica lens (f-number 2.5). The light is focused onto a $1 \mathrm{~m}$ liquid light guide, with a core diameter of $3 \mathrm{~mm}$, which depolarizes the light and brings it to a three-lens f-number matcher. This focuses light onto a $0.1 \mathrm{~mm}$ slit and through a mechanical shutter into an Instruments SA/Jobin Yvon Triax-180 crossed Czerny-Turner triple grating spectrometer (Fraser et al., 2009). The back-illuminated CCD detector with $2048 \times 512$ pixels is thermoelectrically cooled to $201 \mathrm{~K}$. The instrument operated in two viewing modes - zenith sky (ZS) and multiple elevation angles (MD) - and two different wavelength ranges (UV and VIS). For the MD mode a custom-built sun-tracker was placed above the instrument. During twilight, only zenith measurements were taken. The UT-GBS was housed on the ground in an air-conditioned aluminium box $\left(69 \times 126 \times 67 \mathrm{~cm}^{3}\right)$, weighing $100 \mathrm{~kg}$ total. Total power consumption was $2000 \mathrm{~W}$ of power at $120 \mathrm{~V}$.

\section{Washington State University MFDOAS instrument}

MFDOAS instrument (WSU) measures direct-sun (DS) irradiance and scattered sky (SS) radiance using an imaging Czerny-Turner spectrometer (Acton SpectraPro 2356, focal length $300 \mathrm{~mm}$ ) and a back illuminated, UV-coated charge coupled detector (Princeton Instruments PIXIS2 KBUV, $512 \times 2048$ pixels $^{2}\left(6.9 \times 27.6 \mathrm{~mm}^{2}\right)$. SS photons are collected by an off-axis parabolic mirror telescope. The DS field of view is defined by a $2.5 \mathrm{~cm}$ biconvex lens and baffles inside the tube connected to the integrating sphere. Before entering the spectrometer, light passes through two filter wheels that contain UV transmitting filters 
(Hoya U340) for removing visible light and depolarizers (Halbo Optics WDQ25).The observation scheme included vertical scanning combined with direct-sun measurements after 23 June. The instrument positioner (Kipp and Zonen 2APG) is capable of $360^{\circ}$ azimuthal and $90^{\circ}$ zenith rotations. The CCD was cooled to $-70^{\circ} \mathrm{C}$ and the instrument enclosure was temperature regulated at $28 \pm 1{ }^{\circ} \mathrm{C}$. The instrument was located outside at the RSS. The instrument dimension is $0.8 \times 1 \times 1.8 \mathrm{~m}^{3}$, with a total weight $\sim 100 \mathrm{~kg}$. The power consumption is $1.58 \mathrm{~kW}$.

\section{IUP-Heidelberg MAX-DOAS 1 and 2}

The MAX-DOAS instrument 1 of IUP Heidelberg consists of a separate telescope and spectrometer unit, which are connected by a quartz fibre bundle. It was installed at the wind profiler site, where the telescope unit was set-up outdoors and the temperature controlled spectrometer unit indoors under stable conditions. The incoming scattered sunlight is collected via two quartz prisms, whose rotation axes are orthogonal, allowing for the pointing to any direction in the sky. The light is focused by a spherical mirror and distributed to the three miniature Ocean Optics HR2000 spectrometers with a symmetrical crossed Czerny-Turner optical bench with a f/\# of 4 and a linear 2048 pixel CCD array. The MAX-DOAS instrument 2 has a Czerny-Turner spectrograph (Acton 300). Light was detected using a 2-dimensional back-illuminated CCD array with $2048 \times 256$ pixels. Viewing direction sequences with an elevation angle of 2, 4, 8, 15, 30 and $90^{\circ}$ were repeatedly performed, with an integration time per viewing direction of one minute.

\section{A2 SAOZ instruments}

\section{CNRS SAOZ}

The standard SAOZ (Pommereau and Goutail, 1988) as installed at the Wind Profiler site is made of a commercial Jobin-Yvon CP200 flat field spectrometer equipped with a holographic grating of 360 grooves $\mathrm{mm}^{-1}$ associated to a non-cooled 1024 NMOS diode array detector from Hamamatsu and a $50 \mu \mathrm{m}$ entrance slit. The SAOZ is placed in a sealed tight and dehydrated box on the top of which a quartz window is mounted to view at zenith sky. The system is completely automated. A GPS is used for time and solar zenith angle (SZA) accurate calculation. The exposure time is adjusted automatically between 0.1 and $60 \mathrm{~s}$ in order to optimize the signal and the spectra are co-added in memory during a $60 \mathrm{~s}$ duty cycle. During the campaign, measurements were performed every 2 min up to a SZA of $94^{\circ}$. The technical specifications are the following: $70 \mathrm{~cm}$ diameter, $40 \mathrm{~cm}$ height, $28 \mathrm{~kg}$ weight and a power consumption of $500 \mathrm{~W}$ at $220 \mathrm{~V}$.

\section{CNRS mini-SAOZ}

The zenith-sky mini-SAOZ, the new miniaturized version of SAOZ and the first prototype, also participated in the campaign. It is made of a commercial Czerny-Turner spectrometer from Avantes with a $2048 \times 14$ non-cooled CCD detector. Measurements were performed every $2 \mathrm{~min}$. The technical specifications are the following: $20 \times 15 \mathrm{~cm}^{2}, 10 \mathrm{~cm}$ height, $2 \mathrm{~kg}$ weight and $300 \mathrm{~W}$ power at $220 \mathrm{~V}$.

\section{CNRS mobile SAOZ}

The mobile $\mathrm{SAOZ}$ is the balloon version of $\mathrm{SAOZ}$ powered by batteries (in order to allow measurements onboard a car) and in which the conical optical head used usually for directsun observations was replaced by a quartz window and a field of view limiter of $9^{\circ}$ for zenith-sky observations. The scientific specifications are identical to the standard SAOZ. The housing is different and the technical specifications are the following: $50 \times 45 \mathrm{~cm}^{2}, 90 \mathrm{~cm}$ height, $20 \mathrm{~kg}$ weight.

\section{A3 In-situ instruments}

\section{EMPA in-situ}

EMPA measured $\mathrm{NO}$ and $\mathrm{NO}_{2}$ in-situ with a modified commercial chemiluminescence analyser TEI 42C TL (Thermo Fischer Scientific Inc.). Measurements were taken continuously from 12 June to 3 July 2009 at 10 min time resolution. Air was sampled at an altitude of about $3 \mathrm{~m}$ above ground and drawn to the instrument installed in the basement of the tower through a Teflon tubing of about $10 \mathrm{~m}$ length. The instrument measures $\mathrm{NO}$ by detecting the chemiluminescence generated in the reaction of $\mathrm{NO}$ with excess ozone, while $\mathrm{NO}_{2}$ is first reduced to NO by means of a converter (Kley and McFarland, 1980). For the selective measurement of $\mathrm{NO}_{2}$, the standard molybdenum converter was replaced by a photolytic (blue light) converter (Droplet Measurement Technologies, Boulder, Co, USA). Automated daily calibrations included zero and span cycles using a reference gas $(20 \mathrm{ppm}$ NO in $\mathrm{N}_{2}$, Messer-Griesheim, Germany) diluted with purified (NOfree) ambient air, and measurements of the conversion efficiency by gas phase titration. The conversion efficiency was of the order of $45 \%$ during the whole campaign. The total uncertainty $(1 \sigma)$ of the 10 -min samples c were estimated to $\sqrt{0.13^{2}+(0.035 \mathrm{c})^{2}} \mathrm{ppbv}$ and $\sqrt{0.29^{2}+(0.078 \mathrm{c})^{2}} \mathrm{ppbv}$ for $\mathrm{NO}$ and $\mathrm{NO}_{2}$ respectively.

\section{RIVM and LML in-situ}

During the CINDI campaign, RIVM operated three chemiluminescence nitrogen oxides analysers. All three were Model 200E from Teledyne Instruments. One analyser was part of the operational Dutch National Air Quality Monitoring Network (LML), and operated in its standard configuration with a molybdenum converter to convert $\mathrm{NO}_{2}$ to $\mathrm{NO}$. 
The other two were equipped with photolytic converters, also from Teledyne Instruments. The monitor with molybdenum converter was located in the base of the tower at Cabauw, and had its air inlet at $3 \mathrm{~m}$ above the ground. One of the monitors with photolytic converter was using the same air inlet for the first half of the campaign. After 10 July 2009 this monitor was moved to the $100 \mathrm{~m}$ level of the tower. The other monitor with photolytic converter was located at the $200 \mathrm{~m}$ level of the tower for the entire campaign.

\section{IUP-Bremen in-situ}

IUP Bremen operated a commercial nitrogen oxide analyser (Eco Physics CLD 88p) with a photolytic $\mathrm{NO}_{2}$ converter from the same company (PLC 860). During the campaign the same calibration source as for the EMPA instrument has been used. The conversion efficiency was of the order of $60 \%$ throughout the campaign. The Bremen instrument was located in the basement of the tower from 12 June 2009 to 21 July 2009 with the inlet (Teflon tubing) at $3 \mathrm{~m}$ altitude outside the building.

\section{A4 Lidars}

\section{RIVM Caeli lidar}

The lidar Caeli (CESAR water vapour, AErosol and cloud LIdar, Apituley et al., 2009) is a high-performance, multiwavelength Raman lidar, capable of providing round-theclock measurements. The instrument is part of the European Aerosol Research Lidar Network (EARLINET), and provides profiles of volume backscatter and extinction coefficients of aerosol particles, the depolarization ratio, and water-vapour-to-dry-air mixing ratio. A high-power Nd:YAG laser transmits pulses at 355, 532, and $1064 \mathrm{~nm}$. Because a large telescope is essentially blind for lidar signals from close to the instrument, a second, small telescope is used to cover the near range, in particular for measurements in the planetary boundary layer.

\section{RIVM mobile $\mathrm{NO}_{2}$ lidar}

The RIVM mobile lidar instrument uses the DIAL technique (Gimmestad, 2005) to measure $\mathrm{NO}_{2}$ concentrations. The instrument uses a dye laser to send laser pulses, alternating between $413.463 \mathrm{~nm}$ and $414.112 \mathrm{~nm}$, into the atmosphere. A $280 \mathrm{~mm}$ telescope, narrow band interference filter and photomultiplier tube comprise the detector. The laser beam can be pointed in any direction. The measurement range is typically from $300 \mathrm{~m}$ to $2.5 \mathrm{~km}$, sometimes up to $4 \mathrm{~km}$. During the CINDI campaign, measurements at elevation angles of $0.5^{\circ}$, $1^{\circ}, 2^{\circ}, 4^{\circ}, 8^{\circ}, 15^{\circ}, 30^{\circ}$, and $90^{\circ}$ were combined into a single concentration profile. Such a profile takes 5 minutes or more to measure, runs from $5 \mathrm{~m}$ to up to $4 \mathrm{~km}$, and has a vertical resolution ranging from several meters at the bottom to $2 \mathrm{~km}$ at the top of the profile. The entire system is housed in a fully self-supporting mobile laboratory, $8 \mathrm{~m}$ long, $2.5 \mathrm{~m}$ wide and $2.3 \mathrm{~m}$ high, mounted on a vehicle. During the CINDI campaign, it was located on the south-western tip of the Remote Sensing Site. The instrument is extensively described by Volten et al. (2009).

\section{RIVM tropospheric ozone lidar}

The Tropospheric Ozone Lidar, TropO3, was built and operated at RIVM in the Netherlands in the 1990's (Sunesson et al., 1994) for the purpose of routine monitoring of tropospheric ozone. TropO3 is a differential absorption lidar (DIAL) based on two frequency-quadrupled Nd:YAG lasers (FHG), emitting $266 \mathrm{~nm}$ laser light. Stimulated Raman scattering in pressurized gas cells is used to create the DIAL wavelengths $\lambda_{\text {on }}$ at $289 \mathrm{~nm}$ and $\lambda_{\text {off }}$ at $299 \mathrm{~nm}$. The backscattered light is received by a $60 \mathrm{~cm}$ diameter telescope from which ozone profiles are retrieved between approximately $2 \mathrm{~km}$ altitude and $15 \mathrm{~km}$ altitude. A second receiver with a diameter of $5 \mathrm{~cm}$ is used to measure ozone profiles between about $500 \mathrm{~m}$ and $2 \mathrm{~km}$. A full tropospheric ozone profile is measured by averaging data during about 20 to $30 \mathrm{~min}$. Conditions with broken cloud cover of up to 5 octa can be used to provide ozone profiles by rejection of cloud contaminated data. The spatial resolution of the retrieved ozone profiles varies between $100 \mathrm{~m}$ at low altitudes and $1 \mathrm{~km}$ towards the top of the troposphere.

\section{A5 Sondes}

\section{$\mathrm{KNMI} \mathrm{NO}_{2}$ sondes}

Experimental $\mathrm{NO}_{2}$ sondes have flown on 6 days: 18, 23, 24, 25, 30 June, and 1 July, all launched at Cabauw around 10:30 UTC. The sonde uses the chemiluminescent reaction of $\mathrm{NO}_{2}$ in an aqueous luminol solution, which is optimised to be specific to $\mathrm{NO}_{2}$ (Sluis et al., 2010). The sonde is attached to a small meteorological balloon. It has a vertical resolution of $5 \mathrm{~m}$ and a measurement range between 1 and $100 \mathrm{ppbv}$. The instrument weighs $0.7 \mathrm{~kg}$.

\section{KNMI O $\mathrm{O}_{3}$ sondes}

ECC ozone sondes were launched on the same days as the $\mathrm{NO}_{2}$ sondes at 12:30 UTC. The ECC ozone sensor (Komhyr, 1969; Komhyr and Harris, 1971) is an electrochemical cell consisting of two half cells, made of Teflon, which serve as cathode and anode chamber, respectively. Both half cells contain a platinum mesh serving as electrodes. They are immersed in KI solution of different concentrations. The two chambers are linked together by an ion bridge in order to provide an ion pathway and to prevent mixing of the cathode and anode electrolytes. The ECC does not require an external electrical potential. The ECC gets its driving electromotive force from the difference in the concentration of the KI solution in the cathode and anode chamber. The electrical current 
is directly related to the uptake rate of ozone. The sonde is flown in a polystyrene protective box (source: Harris et al., 1998).

\section{Appendix B}

\section{Meteorological parameters}

Daily meteorological values during CINDI are listed in Table B1. For each day the following parameters are listed: average cloud cover, total number of sun hours, average wind direction and wind speed, maximum temperature, average pressure, hours of precipitation, average relative humidity, and average $\mathrm{NO}_{2}$ surface volume mixing ratio between 04:00 and 19:00 UTC (day time). All parameters were measured in Cabauw. The cloud-cover is the average between 06:00 and 18:00 UTC, derived from TSI data (Long et al., 2006). The average $\mathrm{NO}_{2}$ was determined from the in-situ instruments from RIVM, IUP Bremen, and EMPA. Days with at least 10 sunny hours are defined as "category A" days, days with at least 4 sunny hours are defined as "category B" days (indicated in column "cat"). A sunny hour is defined as an hour with less than $50 \%$ cloud cover and with more than $0.5 \mathrm{~h}$ of sunshine, as derived from the hourly meteorological values measured in Cabauw.

\section{Appendix C}

\section{Satellite overpasses}

Table $\mathrm{C} 1$ lists the satellite overpasses during CINDI for GOME-2 aboard EUMETSAT METOP, for SCIAMACHY aboard ESA ENVISAT and for OMI aboard NASA EOSAura. Category A and B days (Sect. 3.1) are indicated in the second column. At some days GOME-2 and OMI had a second overpass. These are not indicated in the table. The retrieved tropospheric $\mathrm{NO}_{2}$ column and its uncertainty are given for the pixel closest to Cabauw. These values are obtained via the Tropospheric Emission Monitoring Internet Service (http://www.temis.nl). No overpass time means: no measurement within $50 \mathrm{~km}$, no $\mathrm{NO}_{2}$ value means: retrieval not trusted because of clouds (cloud radiance fraction $>50 \%$, i.e. cloud cover $>\sim 20 \%$ ) or the socalled "row-anomaly" (for OMI, indicated by an asterisk). Processor versions are: TM4NO2A version 2.10 for GOME2, TM4NO2A version 2.0 for SCIAMACHY, DOMINO version 2.0 for OMI.
Acknowledgements. We gratefully acknowledge the KNMI staff at Cabauw for their excellent technical and infrastructure support during the campaign. The CINDI Campaign was for a large part funded by the ESA project CEOS Intercalibration of ground-based spectrometers and lidars (ESRIN contract 22202/09/I-EC) and the EU project ACCENT-AT2 (GOCE-CT-2004-505337). We further acknowledge the support of the EU via the GEOMon Integrated Project (contract FP6-2005-Global-4-036677). The work of Piters, Kroon, Hains, Boersma and du Piesanie is partly financed by the Netherlands Space Organisation via the SCIAVISIE and OMI Science projects. The work of Vlemmix and Piters is financed by the User Support Programme Space Research via the project "Atmospheric chemistry instrumentation to strengthen satellite validation of CESAR" (EO-091). The Bremen instruments are partly funded by the University of Bremen and the ENVIVAL-life project (50EE0839); their operation is supported by GEOMon and MULTI-TASTE. The participation of the Toronto team was supported by the Canadian Foundation for Climate and Atmospheric Science and the Centre for Global Change Science at the University of Toronto; the instrument was funded by the Natural Sciences and Engineering Research Council and the Canada Foundation for Innovation, and is usually operated at the Polar Environment Atmospheric Research Laboratory (PEARL) by the Canadian Network for the Detection of Atmospheric Change (CANDAC). The work of GIST was supported by a grant from the National Research Foundation of Korea (NRF) funded by the Korean government (MEST) (2008-0060618) through the Advanced Environmental Monitoring Research Center. The work of Clémer was supported by the Belgian Federal Science Policy Office through the AGACC project (contract SD/AT/01A and SD/AT/01B). IUP Heidelberg were partly funded by the EU FP6 Project EUSAAR (2006-026140). The participation of the CNRS team was supported by the French Centre National d'Études Spatiales (CNES) and the instruments were funded by Institut des Sciences de l'Univers (INSU). JAMSTEC were supported by the Japan EOS Promotion Program of the Ministry of Education, Culture, Sports, Science and Technology (MEXT), and by the Global Environment Research Fund (S-7) of the Japanese Ministry of the Environment. The operation of the NIWA instrument during CINDI was partly funded by MULTI-TASTE and the instrument development and data analysis by the New Zealand Foundation for Research, Science and Technology. Washington State University acknowledges funding support from the National Aeronautics and Space Administration, grant NNX09AJ28G. The participation of Roscoe is partly funded by the British Antarctic Survey's Polar Science for Planet Earth program, which is funded by the UK's Natural Environment Research Council. MPIC Mainz were partly funded by EU Seventh Framework Programme FP/2007-2011 under grant 212520, and would like to thank Bastian Jäcker for logistical support. M. Vrekoussis acknowledges the A. von Humboldt foundation and the European Union (EIF-GLYOTRAPTEAM and RG-PARTHENO2N projects) for consecutive research fellowships.

Edited by: J.-P. Pommereau 
Table B1. Average meteorological values during CINDI, see description in Appendix B.

\begin{tabular}{|c|c|c|c|c|c|c|c|c|c|c|}
\hline Date & Cat & $\begin{array}{l}\mathrm{Cc} \\
(\%)\end{array}$ & $\begin{array}{r}\text { Sun } \\
\text { (h) }\end{array}$ & $\begin{array}{r}\text { Wind } \\
\text { dir }\end{array}$ & $\begin{array}{r}\text { Wind } \\
\text { speed } \\
\left(\mathrm{m} \mathrm{s}^{-1}\right)\end{array}$ & $\begin{array}{r}\text { Temp } \\
\text { (C) }\end{array}$ & $\begin{array}{l}\text { Press } \\
(\mathrm{hPa})\end{array}$ & $\begin{array}{r}\text { Precip } \\
\text { (h) }\end{array}$ & $\begin{array}{r}\text { Rel } \\
\text { hum } \\
(\%)\end{array}$ & $\begin{array}{r}\mathrm{NO}_{2} \\
(\mathrm{ppbv})\end{array}$ \\
\hline 8 June 2009 & $\mathrm{~B}$ & 61 & 9.6 & 182 & 3.3 & 18.4 & 1006.9 & 0.9 & 73 & 8.7 \\
\hline 9 June 2009 & & 82 & 4.6 & 212 & 5.3 & 19.6 & 1005.2 & 4.9 & 82 & 8.2 \\
\hline 10 June 2009 & & 99 & 1.0 & 223 & 3.0 & 17.6 & 1011.1 & 6.4 & 85 & 9.8 \\
\hline 11 June 2009 & & 83 & 2.8 & 302 & 4.1 & 17.0 & 1013.7 & 8.4 & 85 & 2.5 \\
\hline 12 June 2009 & A & 13 & 14.4 & 298 & 3.7 & 17.6 & 1021.0 & 0.0 & 73 & 2.9 \\
\hline 13 June 2009 & A & 20 & 12.7 & 179 & 1.8 & 21.6 & 1021.1 & 0.0 & 69 & 3.9 \\
\hline 14 June 2009 & & 93 & 4.0 & 250 & 3.0 & 21.0 & 1017.7 & 4.6 & 84 & 4.8 \\
\hline 15 June 2009 & & 93 & 3.3 & 7 & 1.7 & 18.9 & 1016.6 & 1.3 & 80 & 6.5 \\
\hline 16 June 2009 & & 73 & 5.2 & 5 & 2.6 & 18.4 & 1021.4 & 1.1 & 82 & 7.2 \\
\hline 17 June 2009 & B & 14 & 10.2 & 174 & 3.5 & 23.1 & 1019.8 & 0.0 & 71 & 7.5 \\
\hline 18 June 2009 & $\mathrm{~B}$ & 41 & 7.8 & 269 & 4.0 & 20.4 & 1016.7 & 0.4 & 69 & 4.1 \\
\hline 19 June 2009 & B & 53 & 9.5 & 271 & 5.1 & 18.1 & 1018.5 & 0.0 & 70 & 2.7 \\
\hline 20 June 2009 & & 98 & 6.7 & 284 & 4.1 & 17.5 & 1021.4 & 0.0 & 75 & 2.1 \\
\hline 21 June 2009 & B & 93 & 8.4 & 338 & 3.4 & 17.7 & 1022.8 & 0.5 & 77 & 1.7 \\
\hline 22 June 2009 & B & 63 & 10.4 & 6 & 2.5 & 19.0 & 1027.6 & 0.0 & 74 & 3.4 \\
\hline 23 June 2009 & A & 22 & 14.8 & 21 & 4.3 & 21.3 & 1027.7 & 0.0 & 70 & 4.7 \\
\hline 24 June 2009 & A & 38 & 14.3 & 23 & 5.1 & 22.8 & 1020.9 & 0.0 & 72 & 5.0 \\
\hline 25 June 2009 & B & 41 & 9.1 & 64 & 3.7 & 26.3 & 1013.7 & 0.0 & 64 & 5.7 \\
\hline 26 June 2009 & & 53 & 9.6 & 64 & 2.9 & 24.8 & 1011.7 & 0.0 & 77 & 4.2 \\
\hline 27 June 2009 & & 98 & 4.4 & 332 & 1.8 & 25.4 & 1014.4 & 0.0 & 84 & 6.3 \\
\hline 28 June 2009 & & 93 & 2.2 & 318 & 1.8 & 24.2 & 1016.0 & 0.0 & 91 & 3.6 \\
\hline 29 June 2009 & B & 71 & 8.8 & 329 & 2.5 & 26.1 & 1018.8 & 0.0 & 85 & 3.5 \\
\hline 30 June 2009 & A & 22 & 13.4 & 360 & 3.0 & 25.2 & 1021.4 & 0.0 & 82 & 5.1 \\
\hline 1 July 2009 & B & 38 & 9.9 & 19 & 3.2 & 26.2 & 1022.2 & 0.0 & 80 & 4.1 \\
\hline 2 July 2009 & A & 37 & 12.8 & 48 & 3.0 & 30.2 & 1017.9 & 0.0 & 71 & 5.4 \\
\hline 3 July 2009 & B & 52 & 10.2 & 240 & 4.3 & 28.5 & 1012.9 & 0.0 & 74 & 8.4 \\
\hline 4 July 2009 & A & 8 & 14.2 & 306 & 2.5 & 25.2 & 1013.2 & 0.0 & 72 & 3.5 \\
\hline 5 July 2009 & & 75 & 8.4 & 200 & 2.2 & 27.7 & 1010.3 & 0.4 & 72 & 4.2 \\
\hline 6 July 2009 & & 71 & 8.9 & 231 & 4.0 & 23.1 & 1007.3 & 0.5 & 77 & 4.5 \\
\hline 7 July 2009 & & 95 & 2.8 & 214 & 5.5 & 18.2 & 1003.9 & 4.9 & 86 & 5.7 \\
\hline 8 July 2009 & & 78 & 6.8 & 282 & 5.8 & 19.1 & 1008.3 & 0.5 & 80 & 2.3 \\
\hline 9 July 2009 & & 84 & 4.5 & 266 & 4.0 & 18.5 & 1013.0 & 0.0 & 75 & 3.8 \\
\hline 10 July 2009 & & 92 & 2.1 & 280 & 5.2 & 17.8 & 1013.3 & 6.4 & 82 & 3.0 \\
\hline 11 July 2009 & & 81 & 5.7 & 256 & 3.2 & 20.3 & 1013.8 & 0.1 & 78 & 5.2 \\
\hline 12 July 2009 & & 73 & 5.6 & 216 & 4.4 & 21.4 & 1009.0 & 6.6 & 86 & 4.5 \\
\hline 13 July 2009 & & 59 & 11.3 & 196 & 3.4 & 23.1 & 1010.8 & 0.2 & 73 & 6.1 \\
\hline 14 July 2009 & B & 57 & 8.4 & 237 & 2.0 & 24.4 & 1010.7 & 0.0 & 73 & 7.5 \\
\hline 15 July 2009 & B & 38 & 10.9 & 222 & 4.8 & 24.2 & 1015.9 & 0.0 & 71 & 5.1 \\
\hline 16 July 2009 & A & 27 & 13.9 & 170 & 3.1 & 25.7 & 1018.6 & 0.0 & 65 & 6.3 \\
\hline 17 July 2009 & & 69 & 6.9 & 202 & 5.0 & 22.7 & 1007.2 & 3.0 & 72 & 8.0 \\
\hline 18 July 2009 & & 83 & 4.5 & 237 & 6.0 & 19.6 & 1008.4 & 4.1 & 82 & 3.3 \\
\hline 19 July 2009 & & 74 & 7.3 & 232 & 5.3 & 20.1 & 1011.9 & 1.5 & 77 & 2.4 \\
\hline 20 July 2009 & B & 54 & 8.8 & 242 & 5.1 & 21.0 & 1014.7 & 1.3 & 75 & 4.5 \\
\hline 21 July 2009 & & 85 & 6.5 & 148 & 3.2 & 26.8 & 1009.7 & 1.4 & 80 & 10.5 \\
\hline 22 July 2009 & & 80 & 4.8 & 248 & 3.1 & 24.2 & 1004.6 & 5.1 & 84 & 9.4 \\
\hline 23 July 2009 & & 89 & 2.9 & 226 & 2.8 & 20.5 & 1005.0 & 3.4 & 86 & 9.0 \\
\hline 24 July 2009 & & 70 & 7.5 & 230 & 5.0 & 20.3 & 1011.8 & 1.2 & 80 & 3.9 \\
\hline 25 July 2009 & A & 28 & 13.5 & 273 & 4.3 & 20.6 & 1020.5 & 0.4 & 79 & 3.4 \\
\hline 26 July 2009 & & 74 & 8.0 & 195 & 2.8 & 23.4 & 1018.9 & 0.0 & 74 & 5.4 \\
\hline
\end{tabular}


Table C1. Satellite overpasses during CINDI, see description in Appendix C.

\begin{tabular}{|c|c|c|c|c|c|c|c|}
\hline \multirow[b]{2}{*}{ Date } & \multirow[b]{2}{*}{ Cat } & \multicolumn{2}{|c|}{ GOME-2 } & \multicolumn{2}{|c|}{ SCIAMACHY } & \multicolumn{2}{|c|}{ OMI } \\
\hline & & $\begin{array}{r}\text { Time } \\
\text { [UTC] }\end{array}$ & $\begin{array}{r}\mathrm{NO}_{2} \text { (err) } \\
{\left[10^{15} \mathrm{~cm}^{-2}\right]}\end{array}$ & $\begin{array}{c}\text { Time } \\
\text { [UTC] }\end{array}$ & $\begin{array}{r}\mathrm{NO}_{2} \text { (err) } \\
{\left[10^{15} \mathrm{~cm}^{-2}\right]}\end{array}$ & $\begin{array}{c}\text { Time } \\
\text { [UTC] }\end{array}$ & $\begin{array}{r}\mathrm{NO}_{2} \text { (err) } \\
{\left[10^{15} \mathrm{~cm}^{-2}\right]}\end{array}$ \\
\hline 8 June 2009 & B & $09: 47$ & & & & $11: 55$ & \\
\hline 9 June 2009 & & $09: 26$ & & $10: 39$ & & $12: 38$ & $8(2)$ \\
\hline 10 June 2009 & & $10: 45$ & & $10: 08$ & & $11: 43$ & \\
\hline 11 June 2009 & & $10: 24$ & & & & $12: 26$ & \\
\hline 12 June 2009 & A & $10: 04$ & $9(4)$ & $10: 44$ & $11(7)$ & $11: 31$ & $4.4(1.9)$ \\
\hline 13 June 2009 & A & $9: 43$ & $7(5)$ & $10: 14$ & $12(9)$ & $12: 13$ & $6(4)$ \\
\hline 14 June 2009 & & $9: 22$ & & & & $11: 19$ & \\
\hline 15 June 2009 & & $10: 41$ & & & & $13: 39$ & \\
\hline 16 June 2009 & & $10: 21$ & & & & $12: 44$ & $2(2)$ \\
\hline 17 June 2009 & $\mathrm{~B}$ & $10: 00$ & $16(10)$ & & & $11: 49$ & $14(4)$ \\
\hline 18 June 2009 & B & 09:39 & & & & $12: 31$ & $16(11)$ \\
\hline 19 June 2009 & B & 09:19 & & $10: 25$ & $3.0(1.5)$ & $11: 37$ & \\
\hline 20 June 2009 & & $10: 38$ & & & & $12: 19$ & \\
\hline 21 June 2009 & B & $10: 17$ & & & & $11: 25$ & \\
\hline 22 June 2009 & $\mathrm{~B}$ & $09: 57$ & & & & $12: 07$ & $3.4(1.8)$ \\
\hline 23 June 2009 & A & $09: 36$ & $5(5)$ & $10: 00$ & & $12: 49$ & * \\
\hline 24 June 2009 & A & $09: 15$ & & & & $11: 55$ & $5(3)$ \\
\hline 25 June 2009 & B & $10: 35$ & $12(6)$ & $10: 37$ & $8(5)$ & $12: 38$ & $6(4)$ \\
\hline 26 June 2009 & & $10: 14$ & $12(5)$ & 10:06 & $17(7)$ & $11: 43$ & \\
\hline 27 June 2009 & & $09: 53$ & & & & $12: 25$ & $9(6)$ \\
\hline 28 June 2009 & & $09: 32$ & & $10: 42$ & & $11: 31$ & \\
\hline 29 June 2009 & $\mathrm{~B}$ & $09: 12$ & & $10: 10$ & & $12: 13$ & $13(11)$ \\
\hline 30 June 2009 & A & $10: 31$ & $5(3)$ & & & $11: 19$ & $8(2)$ \\
\hline 1 July 2009 & B & $10: 11$ & $15(9)$ & $10: 49$ & $8(4)$ & $13: 39$ & $5(3)$ \\
\hline 2 July 2009 & A & 09:50 & $5(3)$ & $10: 17$ & $6(4)$ & $12: 44$ & $7(4)$ \\
\hline 3 July 2009 & B & 09:29 & & & & $11: 49$ & \\
\hline 4 July 2009 & A & & & $10: 53$ & $8(5)$ & $12: 31$ & $5(4)$ \\
\hline 5 July 2009 & & $10: 28$ & & $10: 23$ & $6(4)$ & $11: 37$ & \\
\hline 6 July 2009 & & $10: 07$ & & & & $12: 19$ & $6(4)$ \\
\hline 7 July 2009 & & $09: 46$ & & & & $11: 25$ & \\
\hline 8 July 2009 & & $09: 26$ & & $10: 28$ & & $12: 07$ & \\
\hline 9 July 2009 & & $10: 45$ & & & & $12: 49$ & * \\
\hline 10 July 2009 & & $10: 24$ & & & & $11: 55$ & \\
\hline 11 July 2009 & & $10: 04$ & & $10: 35$ & & $12: 37$ & $4(3)$ \\
\hline 12 July 2009 & & $09: 43$ & & $10: 02$ & & $11: 43$ & \\
\hline 13 July 2009 & & $09: 22$ & & & & $14: 04$ & $4(3)$ \\
\hline 14 July 2009 & $\mathrm{~B}$ & $10: 41$ & & $10: 40$ & $13(8)$ & $11: 31$ & \\
\hline 15 July 2009 & $\mathrm{~B}$ & $10: 21$ & & $10: 08$ & & $13: 51$ & $5(2)$ \\
\hline 16 July 2009 & A & $10: 00$ & $14(9)$ & & & $11: 18$ & $10(8)$ \\
\hline 17 July 2009 & & 09:39 & & $10: 44$ & & $13: 39$ & \\
\hline 18 July 2009 & & 09:19 & & $10: 14$ & & $12: 43$ & $1.3(1.8)$ \\
\hline 19 July 2009 & & $10: 38$ & & & & $11: 49$ & \\
\hline 20 July 2009 & $\mathrm{~B}$ & $10: 17$ & $4.8(1.6)$ & $10: 51$ & $6(3)$ & $12: 31$ & $6(3)$ \\
\hline 21 July 2009 & & 09:57 & & & & $11: 37$ & \\
\hline 22 July 2009 & & $09: 36$ & & & & $12: 19$ & $8(6)$ \\
\hline 23 July 2009 & & $09: 15$ & & & & $11: 24$ & \\
\hline 24 July 2009 & & $10: 34$ & & $10: 25$ & & $12: 07$ & \\
\hline 25 July 2009 & $\mathrm{~A}$ & $10: 14$ & & & & $12: 49$ & $*$ \\
\hline 26 July 2009 & & 09:53 & $8(5)$ & & & $11: 55$ & \\
\hline
\end{tabular}

*indicates that there is an OMI overpass, but the measurement is affected by the so-called "row-anomaly". 


\section{References}

Apituley, A., Wilson, K. M., Potma, C., Volten, H., and de Graaf, M.: Performance Assessment and Application of Caeli - A highperformance Raman lidar for diurnal profiling of Water Vapour, Aerosols and Clouds, in: Proceedings of the 8th International Symposium on Tropospheric Profiling, 19-23 October 2009, ISBN 978-90-6960-233-2,Delft, The Netherlands, 2009.

Apituley, A., Hoexum, M., Wilson, K. M., and Potma, C.: Tropospheric Ozone DIAL for Air Quality, Climate Monitoring and Validation Studies, 25th International Laser Radar Conference, 5-9 July 2010, ISBN 978-5-94458-109-9, St. Petersburg, Russia, 862-865, 2010.

Berkhout, A. J. C., van der Hoff, G. R., Bergwerff, J. B., Gast, L. M., Peters, E., and Swart, D. P. J.: Comparison of nitrogen dioxide measurements by lidar and by chemiluminescence monitors, Atmos. Meas. Tech., in preparation, 2012.

Boersma, K. F., Eskes, H. J., Veefkind, J. P., Brinksma, E. J., van der A, R. J., Sneep, M., van den Oord, G. H. J., Levelt, P. F., Stammes, P., Gleason, J. F., and Bucsela, E. J.: Near-real time retrieval of tropospheric $\mathrm{NO}_{2}$ from OMI, Atmos. Chem. Phys., 7, 2103-2118, doi:10.5194/acp-7-2103-2007, 2007.

Brinksma, E. J., Pinardi, G. Braak, R., Volten, H., Richter, A., Schoenhardt, A., Van Roozendael, M., Fayt, C., Hermans, C., Dirksen, R. J., Vlemmix, T., Berkhout, A. J. C., Swart, D. P. J., Oetjen, H., Wittrock, F., Wagner, T., Ibrahim, O. W., de Leeuw, G., Moerman, M., Curier, R. L., Celarier, E. A., Knap, W. H., Veefkind, J. P., Eskes, H. J., Allaart, M., Rothe, R., Piters, A. J. M., and Levelt, P. F.: The 2005 and 2006 DANDELIONS $\mathrm{NO}_{2}$ and Aerosol Intercomparison Campaigns, J. Geophys. Res., 113, D16S46, doi:10.1029/2007JD008808, 2008.

Chen, D., Zhou, B., Beirle, S., Chen, L. M., and Wagner, T.: Tropospheric $\mathrm{NO}_{2}$ column densities deduced from zenith-sky DOAS measurements in Shanghai, China, and their application to satellite validation, Atmos. Chem. Phys., 9, 3641-3662, doi:10.5194/acp-9-3641-2009, 2009.

Clémer, K., Van Roozendael, M., Fayt, C., Hendrick, F., Hermans, C., Pinardi, G., Spurr, R., Wang, P., and De Mazière, M.: Multiple wavelength retrieval of tropospheric aerosol optical properties from MAXDOAS measurements in Beijing, Atmos. Meas. Tech., 3, 863-878, doi:10.5194/amt-3-863-2010, 2010.

Dunlea, E. J., Herndon, S. C., Nelson, D. D., Volkamer, R. M., San Martini, F., Sheehy, P. M., Zahniser, M. S., Shorter, J. H., Wormhoudt, J. C., Lamb, B. K., Allwine, E. J., Gaffney, J. S., Marley, N. A., Grutter, M., Marquez, C., Blanco, S., Cardenas, B., Retama, A., Ramos Villegas, C. R., Kolb, C. E., Molina, L. T., and Molina, M. J.: Evaluation of nitrogen dioxide chemiluminescence monitors in a polluted urban environment, Atmos. Chem. Phys., 7, 2691-2704, doi:10.5194/acp-7-2691-2007, 2007.

Fehsenfeld, F. C., Drummond, J. W., Roychowdhury, U. K., Galvin, P. J., Williams, E. J., Buhr, M. P., Parrish, D. D., Hübler, G., Langford, A. O., Calvert, J. G., Ridley, B. A., Grahek, F., Heikes, B. G., Kok, G. L., Shetter, J. D., Walega, J. G., Elsworth, C. M., Norton, R. B., Fahey, D. W., Murphy, P. C., Hovermale, C., Mohnen, V. A., Demerjian, K. L., Mackay, G. I., and Schiff, H. I.: Intercomparison of $\mathrm{NO}_{2}$ Measurement Techniques, J. Geophys. Res., 95, 3579-3597, doi:10.1029/JD095iD04p03579, 1990.

Fraser, A., Adams, C., Drummond, J. R., Goutail, F., Manney, G., and Strong, K.: The Polar Environment Atmospheric Research Laboratory UV-Visible Ground-Based Spectrometer: First
Measurements of $\mathrm{O}_{3}, \mathrm{NO}_{2}, \mathrm{BrO}$, and $\mathrm{OClO}$ Columns, J. Quant. Spectrosc. Ra., 110, 986-1004, doi:10.1016/j.jqsrt.2009.02.034, 2009.

Frieß, U., Monks, P. S., Remedios, J. J., Rozanov, A., Sinreich, R., Wagner, T., and Platt, U.: MAX-DOAS $\mathrm{O}_{4}$ measurements: A new technique to derive information on atmospheric aerosols: 2. Modeling studies, J. Geophys. Res., 111, D14203, doi:10.1029/2005JD006618, 2006.

Frieß, U., Apituley, A., Beirle, S., Clémer, K., Irie, H., Leeuw, G. de, Peters, E., Richter, A., Van Roozendael, M., Shaiganfar, R., Wagner, T., Vlemmix, T., Weingartner, E., Wittrock, F., Yilmaz, S., and Zieger, P.: Intercomparison of aerosol extinction profiles retrieved from MAX-DOAS measurements of the oxygen collision complex, Atmos. Meas. Tech., in preparation, 2012.

Gimmestad, G. G.: Differential-Absorption Lidar for Ozone and Industrial Emissions, in: Lidar: Range-Resolved Optical Remote Sensing of the Atmosphere, edited by: Weitkamp, C., Springer, New York, 102, 187-212, 2005.

Goutail, F., Pommereau, J.-P., and Sarkissian, A.: Total nitrogen dioxide at the Arctic Polar Circle since 1990, Geophys. Res. Lett., 21, 1371-740, 1994.

Hains, J. C., Boersma, F., Kroon, M., Dirksen, R. J., Cohen, R. C., Perring, A. E., Bucsela, E., Volten, H., Swart, D. P. J., Richter, A., Wittrock, F., Schoenhardt, A., Wagner, T., Ibrahim, O. W., Van Roozendael, M., Pinardi, G., Gleason, J. F., Veefkind, J. P., and Levelt, P. : Testing and improving OMI DOMINO tropospheric $\mathrm{NO}_{2}$ using observations from the DANDELIONS and INTEX-B validation campaigns, J. Geophys. Res. 115, D05301, doi:10.1029/2009JD012399, 2010.

Hak, C., Pundt, I., Trick, S., Kern, C., Platt, U., Dommen, J., Ordóñez, C., Prévôt, A. S. H., Junkermann, W., Astorga-Lloréns, C., Larsen, B. R., Mellqvist, J., Strandberg, A., Yu, Y., Galle, B., Kleffmann, J., Lörzer, J. C., Braathen, G. O., and Volkamer, R.: Intercomparison of four different in-situ techniques for ambient formaldehyde measurements in urban air, Atmos. Chem. Phys., 5, 2881-2900, doi:10.5194/acp-5-2881-2005, 2005.

Harris, N., Hudson, R., and Phillips, C.: SPARC/IOC/GAW Assessment of trends in the vertical distribution of ozone, SPARC Report No. 1., WMO Ozone Research and Monitoring Project Report No. 43, May 1998.

Heckel, A., Richter, A., Tarsu, T., Wittrock, F., Hak, C., Pundt, I., Junkermann, W., and Burrows, J. P.: MAX-DOAS measurements of formaldehyde in the Po-Valley, Atmos. Chem. Phys., 5, 909918, doi:10.5194/acp-5-909-2005, 2005.

Hendrick, F., Barret, B., Van Roozendael, M., Boesch, H., Butz, A., De Mazière, M., Goutail, F., Hermans, C., Lambert, J.C., Pfeilsticker, K., and Pommereau, J.-P.: Retrieval of nitrogen dioxide stratospheric profiles from ground-based zenith-sky UV-visible observations: validation of the technique through correlative comparisons, Atmos. Chem. Phys., 4, 2091-2106, doi:10.5194/acp-4-2091-2004, 2004.

Hoexum, A. M., Apituley, A., Allaart, M. A. F., and Piters, A. J. M.: Tropospheric Ozone Lidar for OMI validation, in: Proceedings of the 8th International Symposium on Tropospheric Profiling, Delft, The Netherlands, 19-23 October 2009.

Hönninger, G., von Friedeburg, C., and Platt, U.: Multi axis differential optical absorption spectroscopy (MAX-DOAS), Atmos. Chem. Phys., 4, 231-254, doi:10.5194/acp-4-231-2004, 2004. 
Holben, B. N., Eck, T. F., Slutsker, I., Tanré, D., Buis, J. P., Setzer, A., Vermote, E., Reagan, J. A., Kaufman, Y., Nakajima, T., Lavenu, F., Jankowiak, I., and Smirnov, A.: AERONET - A federated instrument network and data archive for aerosol characterization, Remote Sens. Environ., 66, 1-16, 1998.

Irie, H., Kanaya, Y., Akimoto, H., Iwabuchi, H., Shimizu, A., and Aoki, K.: First retrieval of tropospheric aerosol profiles using MAX-DOAS and comparison with lidar and sky radiometer measurements, Atmos. Chem. Phys., 8, 341-350, doi:10.5194/acp-8341-2008, 2008.

Irie, H., Takashima, H., Kanaya, Y., Boersma, K. F., Gast, L., Wittrock, F., Brunner, D., Zhou, Y., and Van Roozendael, M.: Eightcomponent retrievals from ground-based MAX-DOAS observations, Atmos. Meas. Tech., 4, 1027-1044, doi:10.5194/amt-41027-2011, 2011.

Kley, D. and McFarland, M.: Chemiluminescence detector for NO and $\mathrm{NO}_{2}$, Atmos. Technol., 12, 63-69, 1980.

Komhyr, W. D.: Electrochemical cells for gas analysis, Ann. Geophys., 25, 203-210, 1969,

http://www.ann-geophys.net/25/203/1969/.

Komhyr, W. D. and Harris, T. B.: Development of an ECC ozonesonde, NOAA Tech. Rep. ERL 200, APCL 18, Boulder, CO, 1971.

Li, X., Brauers, T., Shao, M., Garland, R. M., Wagner, T., Deutschmann, T., and Wahner, A.: MAX-DOAS measurements in southern China: retrieval of aerosol extinctions and validation using ground-based in-situ data, Atmos. Chem. Phys., 10, 20792089, doi:10.5194/acp-10-2079-2010, 2010.

Long, C. N., Sabburg, J. M., Calbó, J., and Pagés, D.: Retrieving Cloud Characteristics from Ground-Based Daytime Color AllSky Images, J. Atmos. Ocean. Tech., 23, 633-652, 2006.

Merlaud, A., et al.: Mobile-DOAS measurements during the CINDI campaign, in preparation, Atmos. Meas. Tech., 2012.

Ohmura, A., Dutton, E. G., Forgan, B., Fröhlich, C., Gilgen, H., Hegner, H., Heimo, A., König-Langlo, G., McArthur, B., Müller, G., Philipona, R., Pinker, R., Whitlock, C. H., Dehne, K., and Wilda, M.: Baseline Surface Radiation Network (BSRN/WCRP): New Precision Radiometry for Climate Research, B. Am. Meteorol. Soc., 79, 2115-2136, 1998.

Pinardi, G., Van Roozendael, M., Adams, C., Beirle, S., Cede, A., Clémer, K., Fayt, C., Frieß, U., Gil, M., Hermans, C., Hendrick, F., Irie, H., Merlaud, A., Peters, E., Piters, A., Puentedura, O., Richter, A., Shaigan, R., Spinei, E., Strong, K., Takashima, H., Wagner, T., Wittrock, F., and Yilmaz, S.: Intercomparison of MAXDOAS formaldehyde slant column measurements during the CINDI campaign, Atmos. Meas. Tech., in preparation, 2012.

Piters, A. J. M.: Report on the Workshop on tropospheric $\mathrm{NO}_{2}$ measured by satellites, available at: http://www.knmi.nl/research/climate_observations/events/

no2_workshop/presentations/NO2_report.pdf, last access: 22 February 2012, De Bilt, The Netherlands, 10-12 September 2007.

Platt, U.: Differential optical absorption spectroscopy (DOAS), Chem. Anal. Series, 127, 27-83, 1994.

Pommereau, J. P. and Goutail, F.: Stratospheric $\mathrm{O}_{3}$ and $\mathrm{NO}_{2}$ Observations at the Southern Polar Circle in summer and fall 1988, Geophys. Res. Lett., 15, 895-897, doi:10.1029/GL015i008p00895, 1988.
Rodgers, C. D.: Inverse Methods for Atmospheric Sounding: Theory and Practice, Series on Atmospheric, Oceanic and Planetary Physics, Vol. 2, World Scientific, Singapore, 2000.

Roscoe, H. K., Johnston, P. V., Van Roozendael, M., Richter, A., Preston, K., Lambert, J.-C., Hermans, C., de Cuyper, W., Dzenius, S., Winterath, T., Burrows, J., Sarkissian, A., Goutail, F., Pommereau, J.-P., d'Almeida, E., Hottier, J., Coureul, C., Ramond, D. Pundt, I., Bartlet, L. M., Kerr, J. E., Elokhov, A., Giovanelli, G., Ravegnani, F., Premudan, M., Kostadinov, M., Erle, F., Wagner, T., Pfeilsticker, K., Kenntner, M., Marquand, L. C., Gil, M., Puentedura, O., Arlander, W., Kastad-Hoiskar, B. A., Tellefsen, C. W., Heese, C. W., Jones, R. L., Aliwalle, S. R., and Freswater, R. A., Slant column measurements of $\mathrm{O}_{3}$ and $\mathrm{NO}_{2}$ during the NDSC intercomparison of zenith-sky UVVisible spectrometers in June 1996, J. Atmos. Chem., 32, 281314, 1999.

Roscoe, H. K., Van Roozendael, M., Fayt, C., du Piesanie, A., Abuhassan, N., Adams, C., Akrami, M., Cede, A., Chong, J., Clémer, K., Friess, U., Gil Ojeda, M., Goutail, F., Graves, R., Griesfeller, A., Grossmann, K., Hemerijckx, G., Hendrick, F., Herman, J., Hermans, C., Irie, H., Johnston, P. V., Kanaya, Y., Kreher, K., Leigh, R., Merlaud, A., Mount, G. H., Navarro, M., Oetjen, H., Pazmino, A., Perez-Camacho, M., Peters, E., Pinardi, G., Puentedura, O., Richter, A., Schönhardt, A., Shaiganfar, R., Spinei, E., Strong, K., Takashima, H., Vlemmix, T., Vrekoussis, M., Wagner, T., Wittrock, F., Yela, M., Yilmaz, S., Boersma, F., Hains, J., Kroon, M., Piters, A., and Kim, Y. J.: Intercomparison of slant column measurements of $\mathrm{NO}_{2}$ and $\mathrm{O}_{4}$ by MAX-DOAS and zenith-sky UV and visible spectrometers, Atmos. Meas. Tech., 3, 1629-1646, doi:10.5194/amt-3-1629-2010, 2010.

Sluis, W. W., Allaart, M. A. F., Piters, A. J. M., and Gast, L. F. L.: The development of a nitrogen dioxide sonde, Atmos. Meas. Tech., 3, 1753-1762, doi:10.5194/amt-3-1753-2010, 2010.

Spinei, E., Mount, G. H., Abuhassan, N., Cede, A., Herman, J., Van Roozendael, M., Clémer, K., Fayt, C., Hendrick, F., Goutail, F., Griesfeller, A., Pazmino, A., and Piters, A. J. M.: Total and tropospheric $\mathrm{NO}_{2}$ column measurements using direct sun, zenith sky and MAX-DOAS techniques during the CINDI campaign, Atmos. Meas. Tech., in preparation, 2012.

Sunesson, J. A., Apituley, A., and Swart, D. P. J.: Differential absorption lidar system for routine monitoring of tropospheric ozone, Appl. Optics, 33, 7045-7058, 1994.

Vandaele, A. C., Fayt, C., Hendrick, F., Hermans, C., Humbled, F., Van Roozendael, M., Gil, M., Navarro, M., Puentedura, O., Yela, M., Braathen, G., Stebel, K., Tørnkvist, K., Johnston, P., Kreher, K., Goutail, F., Mieville, A., Pommereau, J.-P., Khaikine, S., Richter, A., Oetjen, H., Wittrock, F., Bugarski, S., Frieß, U., Pfeilsticker, K., Sinreich, R., Wagner, T., Corlett, G., and Leigh, R.: An intercomparison campaign of ground-based UV-visible measurements of $\mathrm{NO}_{2}, \mathrm{BrO}$, and $\mathrm{OClO}$ slant columns: Methods of analysis and results for $\mathrm{NO}_{2}$, J. Geophys. Res., 110, D08305, doi:10.1029/2004JD005423, 2005.

Vlemmix, T., Piters, A. J. M., Berkhout, A. J. C., Gast, L. F. L., Wang, P., and Levelt, P. F.: Ability of the MAX-DOAS method to derive profile information for $\mathrm{NO}_{2}$ : can the boundary layer and free troposphere be separated?, Atmos. Meas. Tech., 4, 26592684, doi:10.5194/amt-4-2659-2011, 2011. 
Volten, H., Brinksma, E. J., Berkhout, A. J. C., Hains, J., Bergwerff, J. B., Van der Hoff, G. R., Apituley, A., Dirksen, R. J., Calabretta-Jongen, S., and Swart, D. P. J.: $\mathrm{NO}_{2}$ lidar profile measurements for satellite interpretation and validation, J. Geophys. Res., 114, D24301, doi:10.1029/2009JD012441, 2009.

Wagner, T., Beirle, S., Brauers, T., Deutschmann, T., Frieß, U., Hak, C., Halla, J. D., Heue, K. P., Junkermann, W., Li, X., Platt, U., and Pundt-Gruber, I.: Inversion of tropospheric profiles of aerosol extinction and $\mathrm{HCHO}$ and $\mathrm{NO}_{2}$ mixing ratios from MAX-DOAS observations in Milano during the summer of 2003 and comparison with independent data sets, Atmos. Meas. Tech., 4, 2685-2715, doi:10.5194/amt-4-2685-2011, 2011.

Winer, A. M., Peters, J. W., Smith, J. P., and Pitts, J. N.: Response of commercial chemiluminescent $\mathrm{NO}-\mathrm{NO}_{2}$ analyzers to other nitrogen-containing compounds, Environ. Sci. Technol., 8, 1118-1121, doi:10.1021/es60098a004, 1974.

Wittrock, F., Oetjen, H., Richter, A., Fietkau, S., Medeke, T., Rozanov, A., and Burrows, J. P.: MAX-DOAS measurements of atmospheric trace gases in Ny-Ålesund - Radiative transfer studies and their application, Atmos. Chem. Phys., 4, 955-966, doi:10.5194/acp-4-955-2004, 2004.
Wittrock, F., Clémer, K., Beirle, S., Berkhout, S., Brunner, D., Frieß, U., Hay, T., Irie, H., Kreher, K., Oetjen, H., Peters, E., Richter, A., Van Roozendael, M., Sluis, W., Spinei, E., Wagner, T., Boersma, F., Kroon, M., and Piters, A.: Measurements of $\mathrm{NO}_{2}$ profiles with MAX-DOAS: Theoretical and practical case studies as part of the Cabauw Intercomparison campaign for $\mathrm{Ni}$ trogen Dioxide Measuring Instruments (CINDI), Atmos. Meas. Tech., in preparation, 2012.

WMO/GAW, Report no. 153: Aerosol measurement procedures guidelines and recommendations, WMO TD No. 1178, 2003.

Zieger, P., Weingartner, E., Henzing, J., Moerman, M., de Leeuw, G., Mikkilä, J., Ehn, M., Petäjä, T., Clémer, K., van Roozendael, M., Yilmaz, S., Frieß, U., Irie, H., Wagner, T., Shaiganfar, R., Beirle, S., Apituley, A., Wilson, K., and Baltensperger, U.: Comparison of ambient aerosol extinction coefficients obtained from in-situ, MAX-DOAS and LIDAR measurements at Cabauw, Atmos. Chem. Phys., 11, 2603-2624, doi:10.5194/acp11-2603-2011, 2011. 